\title{
The Role of Microfabric and Laminae on Pore Structure and Gas Transport Pathways of Marine Shales from Sichuan Basin, China
}

\author{
Yi Shu, ${ }^{1}$ Shang Xu $\mathbb{D}^{1}{ }^{1}$ Feng Yang ${ }^{\circ},{ }^{1}$ Zhiguo Shu, $^{2}$ Pan Peng, ${ }^{3}$ Senxin Huang, ${ }^{1}$ and He Zhen ${ }^{1}$ \\ ${ }^{1}$ Key Laboratory of Tectonics and Petroleum Resources (China University of Geosciences), Ministry of Education, \\ Wuhan 430074, China \\ ${ }^{2}$ Research Institute of Petroleum Exploration and Development, SINOPEC Jianghan Oilfield Company, Wuhan 430223, China \\ ${ }^{3}$ Shenzhen Branch, CNOOC China Limited, Shenzhen 518000, China
}

Correspondence should be addressed to Shang Xu; xushang0222@163.com and Feng Yang; fengyang@cug.edu.cn

Received 13 April 2020; Revised 12 June 2020; Accepted 20 June 2020; Published 21 July 2020

Academic Editor: Keliu Wu

Copyright (c) 2020 Yi Shu et al. This is an open access article distributed under the Creative Commons Attribution License, which permits unrestricted use, distribution, and reproduction in any medium, provided the original work is properly cited.

\begin{abstract}
This study investigated the effects of microfabric and laminae on the pore structure and gas transport pathways of the Silurian Longmaxi shales from Sichuan Basin. 23 shale samples with varied lithofacies were comprehensively investigated by mineralogy, organic geochemistry, pycnometry, and low-pressure nitrogen adsorption analysis. The fabric and laminae of these samples were identified using petrographic microscope and scanning electron microscopy. Permeabilities were measured using the nonsteadystate method on both perpendicular and parallel to bedding shales. The effective pore diameter controlling gas transport was estimated from gas slippage factors obtained in permeability measurements. These values were also compared to those calculated using the Winland equation. Siliceous shales studied are faintly laminated to nonlaminated and have larger porosity and specific surface area. Argillaceous/siliceous mixed shales are well laminated, whereas argillaceous shales contain many oriented clay flakes along the lamination. Both porosity and surface area are positively correlated with TOC content. Unlike most conventional reservoirs, there is a negative correlation between porosity and permeability values of the samples studied. Permeabilities parallel to bedding, ranging from 0.4 to $76.6 \mu \mathrm{D}$, are in control of the oriented clay flakes and silty microlaminae. Permeability anisotropy values of the shales vary between 1.3 and 49.8. Samples rich in oriented clay flakes and microlaminated fabric have relatively larger permeability and permeability anisotropy values. The effective transport pore diameters derived from gas slippage measurements are slightly lower than those calculated from the Winland equation. However, both methods have shown that the effective transport pore diameters of argillaceous shales (averaging $552 \mathrm{~nm}$ ) are significantly higher than siliceous shales (averaging $198 \mathrm{~nm}$ ), which underlines the control of microfabric, rather than porosity, on gas transport pathways of the shales studied.
\end{abstract}

\section{Introduction}

Shale systems have received increased research activities since hydrocarbons have been commercially extracted from unconventional reservoirs. Shale reservoirs consist of various fine-grained sedimentary rocks that mainly include mudrocks, shales, and siltstones [1-3]. Due to the large variability in lithology and involvement of organic matter, reservoir characteristics of shales are very complex. To characterize the complex pore structure, innovative approaches are implemented to obtain information about the nanometer- to micrometer-sized pore systems of shales
[4-8]. A variety of organic matter-hosted and inorganic matter-related pores with pore size ranging from micropore $(<2 \mathrm{~nm}$, IUPAC classification) to mesopore $(2-50 \mathrm{~nm}$, IUPAC classification) to macropore $(>50 \mathrm{~nm}$, IUPAC classification) have been reported in shales [9-11]. Pore structure characteristics (morphology, porosity, pore size distribution, and specific surface area) of shales are found to be associated with rock composition, total organic carbon (TOC) content, maturity, and other geological factors [12-16].

Permeability is one of the most important petrophysical parameters for reservoir evaluation and hydrocarbon production [17, 18]. Since shale reservoirs commonly have 
permeabilities down to micro- to nano-Darcy range, steady and nonsteady-state flow tests are employed to determine the permeability values of shales [19]. Permeabilities are affected by many geological factors, including fabric, lithology, mineralogy, pore size distribution (PSD), and microfractures. Studies on high-maturity Horn River shales have shown that the matrix permeabilities were largely related to the connectivity between macropores and micropores [20]. Permeability values of coarser grained sandstones are commonly higher than those of finer grained mudstones by several orders of magnitude [21]. Permeabilities are further affected by diagenetic process. Mechanical compaction and mineral cementation can significantly decrease pore space and fluid transport pathways of rocks. Clay minerals are reported to cement with the framework minerals and thus decrease permeability of Eagle Ford shales [22]. It should be noted that most of the samples in these studies are lowmaturity or organic-lean, and most porosity is associated with the interparticle pores of inorganic matter. Recently, advanced scanning electron microscopy has documented diverse pores in shale systems $[6,16]$. However, there are relatively few detailed studies to relate pore structure to the transport properties of shales. Especially, organic matter- (OM-) hosted pores are critical for gas adsorption in many overmature marine shales [23-25], but the role of OM-hosted pores on fluid storage and transport needs more study in detail. Furthermore, permeability can be estimated from more easily determined petrophysical properties, such as mean pore diameter and pore throat size distribution [26, 27]. However, many pore space analysis methods are conducted at atmospheric pressure. It would be much more meaningful to apply these pore structure parameters in the estimations of permeability under in situ conditions $[19,28]$. What is more, the effective pore diameter for gas transport can be further derived from gas slippage in gas permeability measurements [29]. These link a direct relationship between pore structure and gas transport.

Concerns about the economic potential of shale systems have led to many studies about reservoir properties of shales $[12,30,31]$. Significant progresses have been achieved in basin structure, sedimentology environment, organic geochemistry, and petrophysical features of shales $[17,32-36]$. Shales are commonly composed of finegrained minerals intercalated with coarser-grained quartz and carbonate microlaminae. High-frequency laminations and strong heterogeneities probably lead to different permeability values and significant permeability anisotropy even on the same formation [37, 38]. Gas transport in shales is controlled not only by geometry (pore size distribution) but also topology of pores (connectivity, preferential pathways, etc.) [39]. Although some studies have documented the heterogeneities and the pore systems associated with facies in gas shales $[30,40,41]$, the effects of microfabric and laminae on gas flow are not yet described in detail.

We report on a suite of shale samples that represent various properties from the Jiaoshiba area, Sichuan Basin, China. This study examines the role of microfabric and laminae on pore space and transport properties of shales. With a combination of imaging observation (petrographic microscope and scanning electron microscope) and fluid invasion measurements (helium expansion porosimetry, low-pressure $\mathrm{N}_{2}$ adsorption-desorption, and pulse-decay $\mathrm{N}_{2}$ tests), petrophysical properties of Longmaxi shales are comprehensively characterized. Pore structures of various shales are qualitatively described. The effects of minerals and microfabric on porosity, PSD, and pore structure of shales are discussed. Furthermore, both the Winland equation and gas permeability measurements are applied to calculate the effective pore diameter. Hereby, controls of microfabric and laminae on gas transport on shales are assessed.

\section{Geological Background}

Jiaoshiba shale gas field, the first commercially developed shale reservoirs in China, is located in the Fuling District, Chongqing Municipality, in the eastern Sichuan Basin (Figure 1). Gas production in the Jiaoshiba shale reservoir is reported to be up to $50 \times 10^{4} \mathrm{~m}^{3} /$ day per well [42]. The Jiaoshiba structure is a wide and gentle anticline, constrained by two sets of northeast-trending faults [43-45]. As a part of Sichuan Basin, the Jiaoshiba structure was subjected to multistage tectonic movements during the formation of Yangtze platform $[43,46]$. In Late Ordovician-Early Silurian time, the Sichuan Basin transformed from a passive continental margin basin to a foreland basin. Because of the uplift in the southern, central, and eastern boundaries, the Sichuan Basin formed a shelf structure of being open on the northern side. Correspondingly, the sedimentary environment was undercompensated and anoxic in the study area [47-49]. There were two global transgressions at the end of Ordovician period and the beginning of Silurian period $[50,51]$, which caused the deposition of Ordovician WufengSilurian Longmaxi $\left(\mathrm{O}_{3} \mathrm{w}-\mathrm{S}_{1} \mathrm{l}\right)$ shale system. After that, the sea level gradually declined. A mass of terrigenous detrital materials were involved in the middle and late deposition of $\mathrm{S}_{1} 1$ Formation [49].

From the lower to upper sections of $\mathrm{O}_{3} \mathrm{w}-\mathrm{S}_{1} 1$ shales, the sedimentary facies transformed gradually from deep-water shelf to shallow-water shelf [52]. The $\mathrm{O}_{3} \mathrm{w}-\mathrm{S}_{1} 1$ shales can be approximately divided into three members based on lithological features. The lower member of the Longmaxi shales (including the $\mathrm{O}_{3} \mathrm{w}$ formation), deposited in a deep-water shelf sedimentary environment, is dominated by dark gray and black siliceous shales. A lot of benthic algae, radiolarian, graptolite, and radiolarian fossils are documented in the lower section of Longmaxi shales previously [52], which provide organic matter for siliceous shales [16]. At the same time, the sedimentary environment was anoxic and euxinic when siliceous shales were deposited, which is beneficial to the preservation of organic matter in siliceous shales [47]. The middle part of Longmaxi Formation is basin-slope facies. Compared to the early deposition of Longmaxi shales, the supply of terrigenous clasts at the middle Longmaxi Formation was significantly increased $[46,52]$. Consequently, lithological features of the shales gradually converted from siliceous into silt-bearing shales. Silty laminae are developed well in the middle part of Longmaxi shales. The upper section was formed in shallow-water shelf environments [48]. Shales 


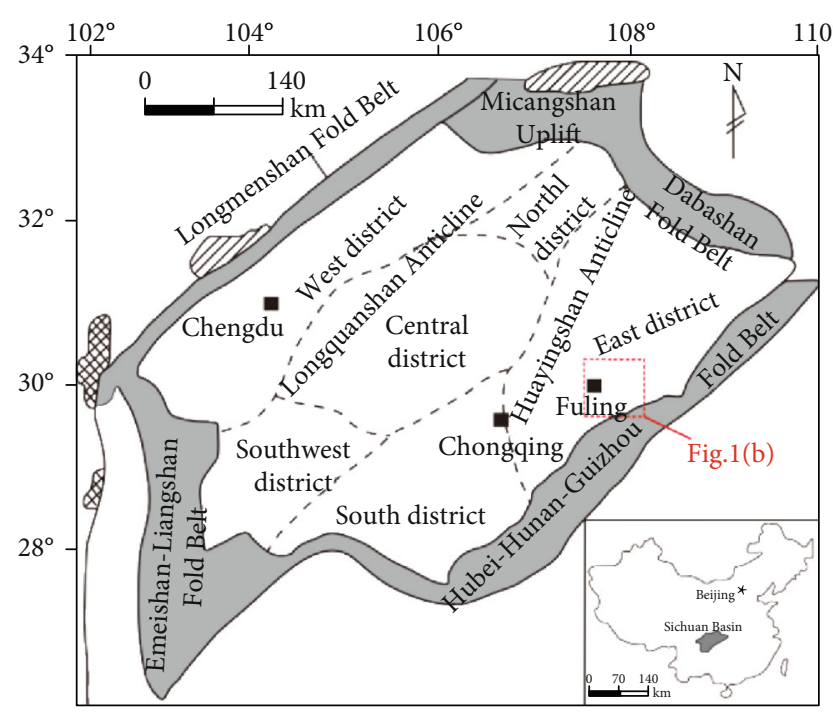

$\square X$ Precambrian igneous

WIII Pre-sinian

$\rightarrow$ Boundary of secondorder structural units
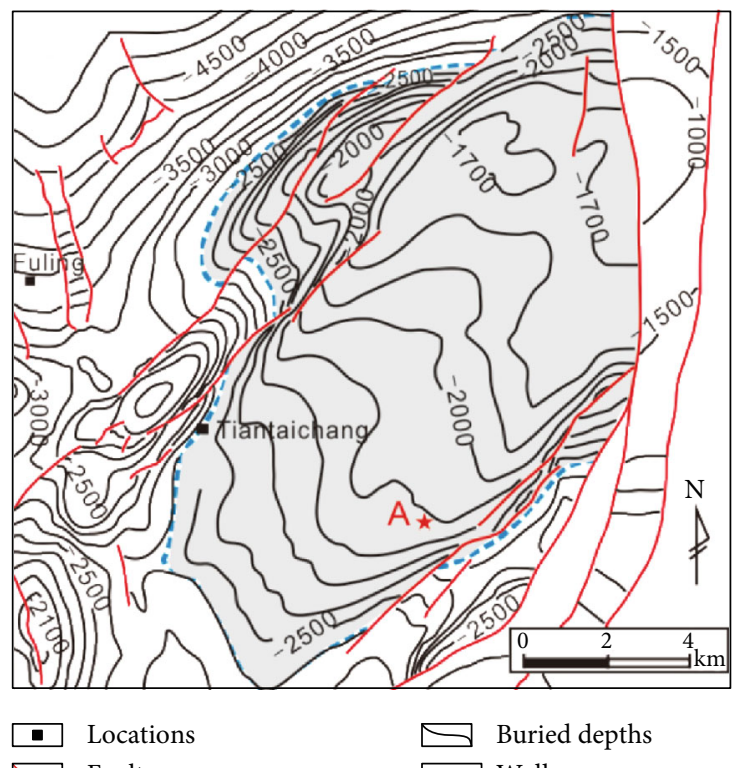

$\rightleftharpoons$ Faults $\rightleftharpoons$ Buried depths

* Wells

(a)

(b)

Figure 1: Geological structure of the Sichuan Basin (modified after [44]). (a) Location of the study area in Sichuan Basin. (b) Tectonic map of the Jiaoshiba area, the top buried depth map of Longmaxi formation, and sampled shale gas well A.

TABLE 1: Lithofacies, TOC, and mineralogy compositions of the Longmaxi shale samples. TOC and mineral content are presented in weight percent (wt \%).

\begin{tabular}{|c|c|c|c|c|c|c|c|c|c|c|c|}
\hline Sample & Depth $(\mathrm{m})$ & Lithofacies & TOC & Quartz & Total feldspar & Carbonates & Pyrite & Total clays & $\mathrm{I} / \mathrm{S}$ & Illite & Chlorite \\
\hline JYA-1 & 2527.8 & $\mathrm{CM}$ & 0.5 & 33.3 & 8.6 & 0.0 & 1.8 & 56.3 & 19.7 & 11.3 & 25.3 \\
\hline JYA-2 & 2531.1 & $\mathrm{CM}$ & 0.3 & 31.1 & 6.2 & 0.0 & 0.0 & 62.7 & 18.8 & 17.6 & 26.3 \\
\hline JYA-3 & 2537.1 & $\mathrm{CM}$ & 0.6 & 30.5 & 7.0 & 2.2 & 1.5 & 58.8 & 21.2 & 16.5 & 21.2 \\
\hline JYA-4 & 2540.5 & $\mathrm{CM}$ & 1.0 & 32.2 & 8.1 & 2.2 & 1.9 & 55.6 & 20.0 & 16.7 & 18.9 \\
\hline JYA-5 & 2543.1 & $\mathrm{CM}$ & 1.4 & 34.7 & 4.2 & 5.0 & 3.3 & 52.8 & 15.8 & 15.8 & 21.1 \\
\hline JYA-6 & 2549.2 & M & 2.3 & 32.3 & 6.0 & 10.9 & 3.9 & 46.9 & 19.2 & 10.8 & 16.9 \\
\hline JYA-7 & 2551.2 & $\mathrm{CM}$ & 1.5 & 33.1 & 3.7 & 3.7 & 1.7 & 57.8 & 16.8 & 17.9 & 23.1 \\
\hline JYA-8 & 2553.1 & $\mathrm{CM}$ & 1.7 & 35.3 & 5.7 & 2.3 & 1.5 & 55.2 & 17.7 & 16.6 & 21.0 \\
\hline JYA-9 & 2563.1 & M & 1.4 & 37.4 & 8.2 & 10.0 & 3.0 & 41.4 & 17.4 & 14.9 & 9.1 \\
\hline JYA-10 & 2563.4 & $\mathrm{M}$ & 2.0 & 38.1 & 7.6 & 9.1 & 4.0 & 41.2 & 14.4 & 14.4 & 12.4 \\
\hline JYA-11 & 2569.3 & M & 1.4 & 35.9 & 9.7 & 11.7 & 1.9 & 40.8 & 16.7 & 11.4 & 12.6 \\
\hline JYA-12 & 2579.4 & M & 2.3 & 37.2 & 6.2 & 5.9 & 2.2 & 48.5 & 17.5 & 15.5 & 15.5 \\
\hline JYA-13 & 2582.0 & $S$ & 2.5 & 38.4 & 9.3 & 11.9 & 5.5 & 34.9 & 12.2 & 16.1 & 6.6 \\
\hline JYA-14 & 2585.4 & $S$ & 3.1 & 40.6 & 7.6 & 9.8 & 5.1 & 36.9 & 19.2 & 11.4 & 6.3 \\
\hline JYA-15 & 2587.2 & $S$ & 3.0 & 44.7 & 7.2 & 6.8 & 4.1 & 37.2 & 18.2 & 14.1 & 4.8 \\
\hline JYA-16 & 2593.0 & M & 1.4 & 30.6 & 7.5 & 36.6 & 3.4 & 21.9 & 10.7 & 7.0 & 4.2 \\
\hline JYA-17 & 2594.0 & S & 2.6 & 41.3 & 7.0 & 13.9 & 4.0 & 33.8 & 15.6 & 11.8 & 6.4 \\
\hline JYA-18 & 2597.3 & S & 3.0 & 47.1 & 7.2 & 12.6 & 6.6 & 26.5 & 13.0 & 10.3 & 3.2 \\
\hline JYA-19 & 2600.1 & S & 3.0 & 45.2 & 7.9 & 14.5 & 4.0 & 28.4 & 13.6 & 11.1 & 3.7 \\
\hline JYA-20 & 2603.3 & S & 3.0 & 38.5 & 12.9 & 19.4 & 4.9 & 24.3 & 10.5 & 11.2 & 2.7 \\
\hline JYA-21 & 2606.2 & S & 4.0 & 53.2 & 10.5 & 7.3 & 3.8 & 25.2 & 13.6 & 8.8 & 2.8 \\
\hline JYA-22 & 2612.2 & S & 4.4 & 49.3 & 8.10 & 6.3 & 4.3 & 32.0 & 16.3 & 14.1 & 1.6 \\
\hline JYA-23 & 2615.3 & S & 5.3 & 58.4 & 3.50 & 8.1 & 5.5 & 24.5 & 13.2 & 8.3 & 2.9 \\
\hline
\end{tabular}




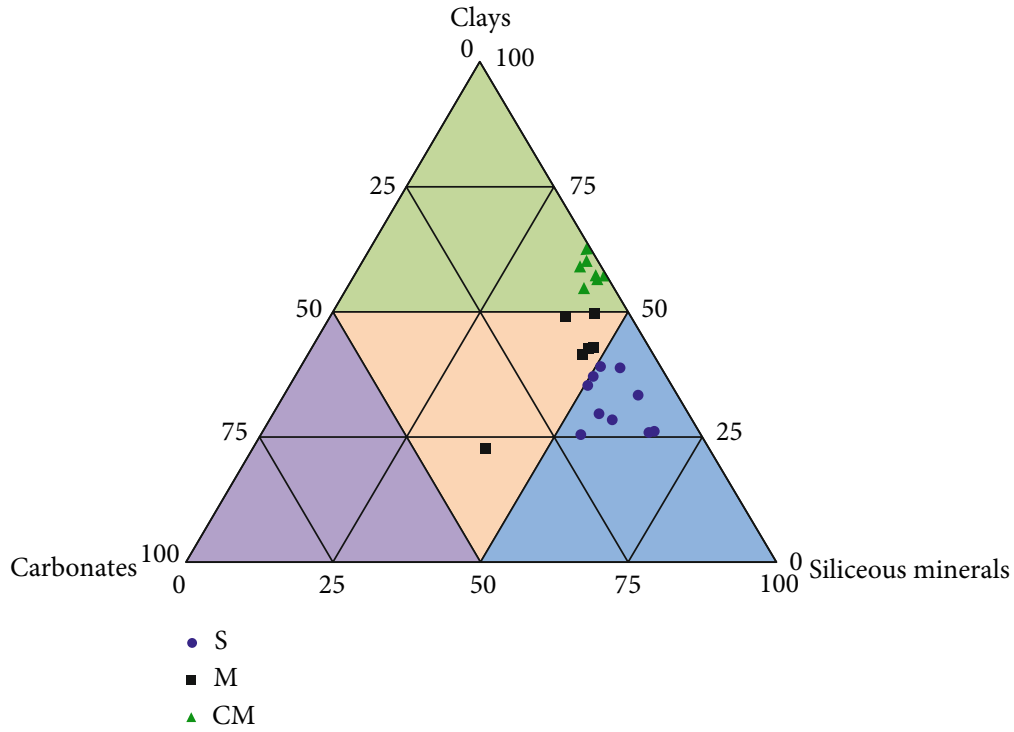

FIGURE 2: Ternary diagram of the mineralogy of the Silurian shale samples. Shale samples were classified into three groups: siliceous shale lithofacies (S), argillaceous/siliceous/calcareous mixed shale lithofacies (M), and silica-rich argillaceous shale lithofacies (CM).

in the upper section are dominated by light gray mudstones and siltstones [52]. The variability of lithology from the lower to the upper member of the Longmaxi shales in Jiaoshiba area offers a suitable case for assessing the relationship between shale lithofacies and reservoir characteristics. The Longmaxi Formation in the Jiaoshiba area varies in thickness from 60 to $150 \mathrm{~m}$. Longmaxi shales with the vitrinite reflectance equivalent values being higher than $2.0 \%$ are highly overmatured $[25,47]$.

\section{Experimental Section}

3.1. Sample Preparation. Marine shale samples were collected from the lower to upper section of Longmaxi Formation. Twenty-three samples with depth ranging from 2527.8 to $2615.3 \mathrm{~m}$ were obtained from a shale gas well drilled in the Jiaoshiba shale gas field (Table 1). Samples were selected to cover the variability of total organic carbon (TOC), inorganic minerals composition, and shale lithofacies. 21 cylindrical plugs with $25-40 \mathrm{~mm}$ in length and $25.4 \mathrm{~mm}$ (1 inch) in diameter were drilled parallel to the bedding, and 8 plugs were drilled perpendicular to bedding. Cylindrical plugs were dried in a vacuum oven $\left(105^{\circ} \mathrm{C}\right)$ for at least $12 \mathrm{~h}$ before porosity and permeability measurements. Petrologic and scanning electron microscope analyses were carried out on subsamples (fragments). Mineralogical components, TOC content, and low-pressure nitrogen adsorption-desorption analyses were performed on dry particles $(0.15 \mathrm{~mm}$ particle size $)$.

3.2. Imaging Methods. Petrologic observations were conducted on polished thin sections to analyze the rock fabric, texture, microorganism, and mineralogy. Polished thin sections with thickness between 0.02 and $0.06 \mathrm{~mm}$ were prepared and photographed using a Leica DMRX microscope.

Visual pore structure was observed on a Zeiss Merlin Compact field emission-scanning electron microscope (FE-

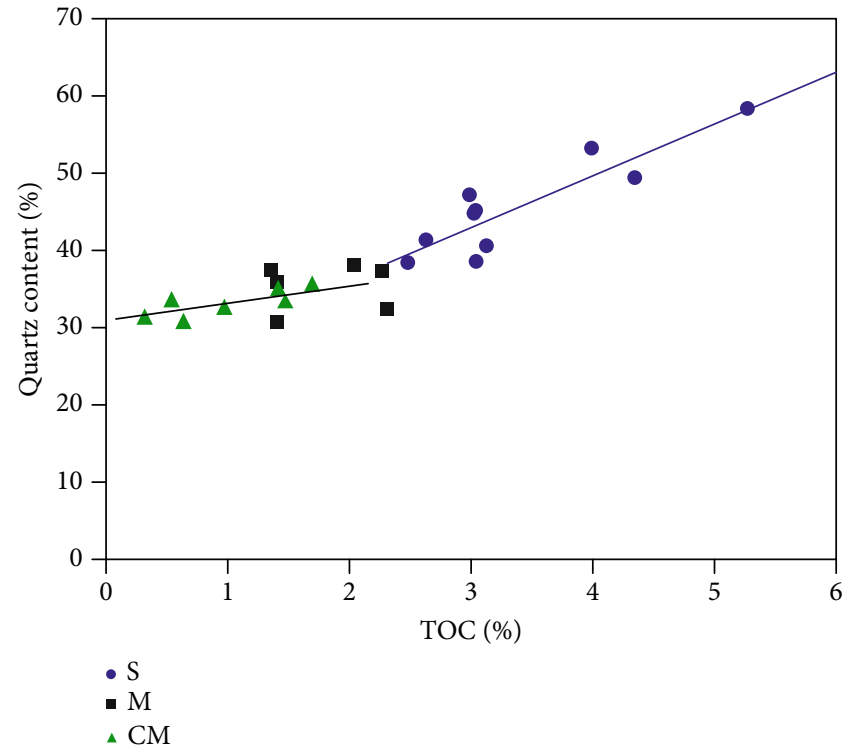

FIgURe 3: Relationship between TOC content and quartz content of shale samples. There is obviously a stronger positive relationship between TOC content and quartz content in organic-rich siliceous shale lithofacies (S) samples.

SEM). This apparatus is equipped with backscattered electron (BSE) and secondary electron (SE) detectors and achieves the highest pixel resolution of about $0.8 \mathrm{~nm}$ at $15 \mathrm{kV}$ operating voltage. Shale samples were ion polished and coated with gold before the visual observations.

3.3. Low-Pressure Low-Temperature Nitrogen (N2) Adsorption. Low-pressure $\mathrm{N}_{2}$ adsorption-desorption experiments at $-196^{\circ} \mathrm{C}(77 \mathrm{~K})$ were performed to obtain information about the specific surface area, pore size distribution (PSD), and pore volume. Powder shales were first degassed 


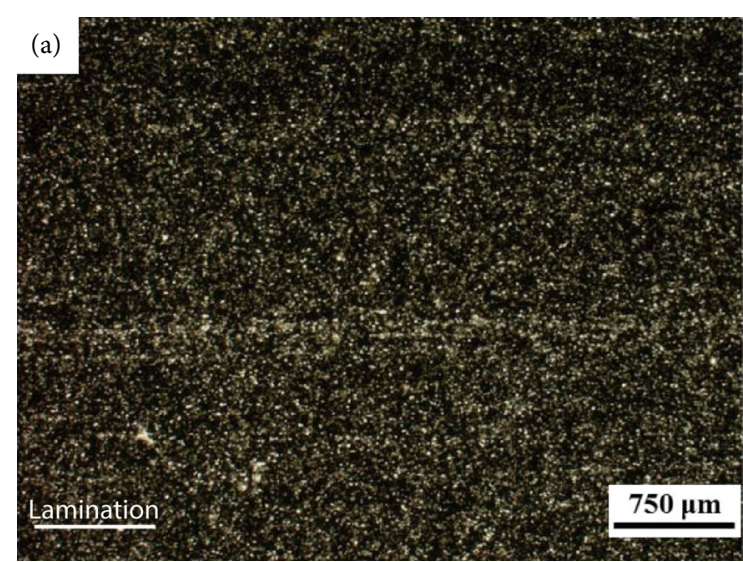

(a)

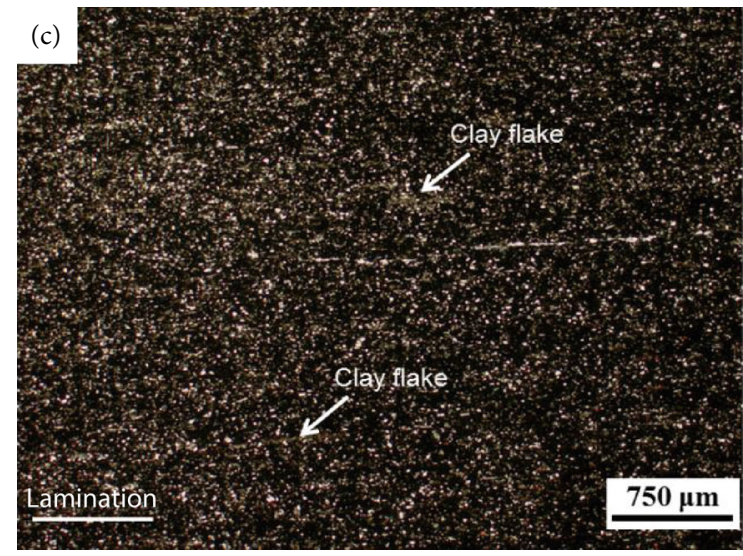

(c)

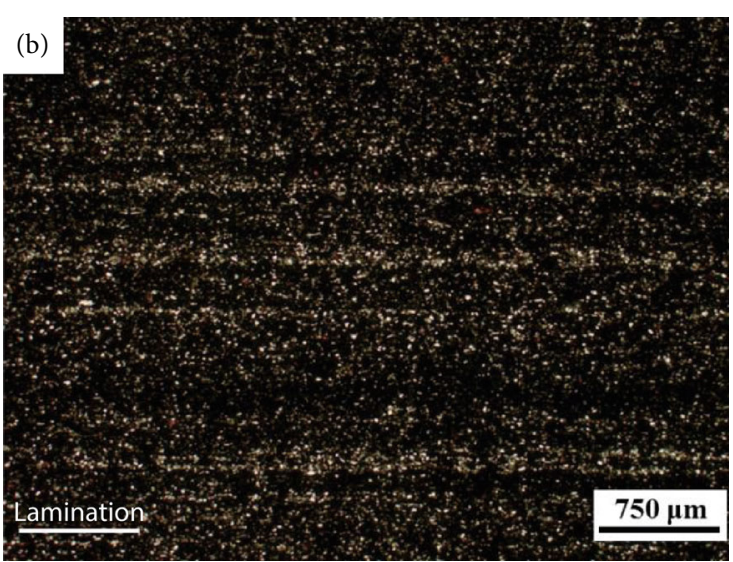

(b)

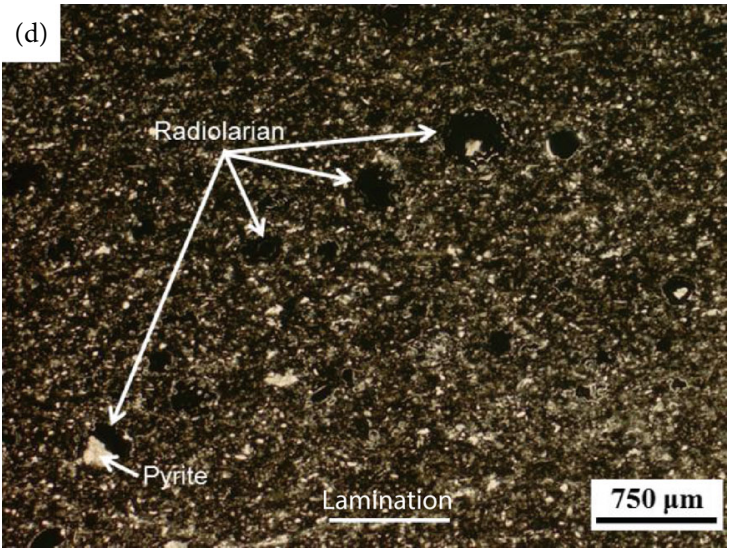

(d)

FIgURE 4: Transmitted light thin section images of siliceous shale lithofacies (S). (a) Faint laminae of silty quartz. JYA-17, $K_{\mathrm{h}}=24.4 \mu \mathrm{D}$, $2594.03 \mathrm{~m}$. (b) Slight laminae of silty quartz. Mixed organic matter and clays (black) distributed between the laminae. JYA-18, $K_{\mathrm{h}}=14.95 \mu \mathrm{D}$, permeability anisotropy $(\beta)=9.3,2597.3 \mathrm{~m}$. (c) No obvious lamina is observed. Miniature lenticular clay flakes distributed along the lamination. JYA-22, $K_{\mathrm{h}}=0.4 \mu \mathrm{D}$, permeability anisotropy $(\beta)=1.3,2612.2 \mathrm{~m}$. (d) Nonlaminated siliceous shale. Abundant radiolarians are observed. Some radiolarians are replaced by pyrite. JYA-23, $2615.29 \mathrm{~m}$.

overnight at $105^{\circ} \mathrm{C}$ in a vacuum chamber. $\mathrm{N}_{2}$ adsorption and desorption isotherms were obtained by collecting adsorption data on degassed samples at a pressure up to $730 \mathrm{~mm} \mathrm{Hg}$. The nitrogen adsorption data were interpreted to obtain specific surface area and PSD according to Brunauer-Emmett-Teller (BET) and Barrett-Joyner-Halenda (BJH) theories [53].

3.4. Helium Pycnometry and Gas Permeability. Helium pycnometry was applied on dried cylindrical plugs to determine the skeletal density $\left(\rho_{\text {skeletal }}\right)$. The bulk density $\left(\rho_{\text {bulk }}\right)$ of these plugs was measured from the geometric dimensioning of cylindrical plugs using a caliper and the weight of samples. Then, porosity values $(\phi)$ under unconfined conditions were determined from the bulk density and skeletal density values according to $\phi=1-\rho_{\text {bulk }} / \rho_{\text {skeletal }}$.

Gas permeability coefficients were measured on dried cylindrical samples using $\mathrm{N}_{2}$ as measuring gas at room temperature. Sample plugs were placed in a customer-designed pulse-decay permeameter (PDP-200, Core Lab) at a selected confining pressure of 2000 PSI. Small pressure pulses of about $0.5-1.0 \mathrm{MPa}$ were introduced to the upstream reservoir, and the pressures of the upstream and downstream reservoirs were monitored with high-precision pressure transducers. Different average pore pressures are obtained via introducing several small-pressure pulses. The nonsteady-state nitrogen permeability at different pore pressures was determined using a linear regression performed on the pressure time data according to the fundamental flow equations [37]. The measured nitrogen permeability was corrected using the Klinkenberg method based on the permeability values at different pore pressures [29].

\section{Results}

4.1. Mineralogy and TOC Content. Mineralogy compositions of the studied Longmaxi samples are illustrated in Figure 2. The Jiaoshiba shale samples mainly consist of quartz (30.5$58.4 \%)$ and clay minerals (21.9-62.7\%) with a minor amount of plagioclase $(3.5-9.9 \%)$, dolomite $(0-32.2 \%)$, calcite $(0-$ $8.4 \%)$, pyrite $(0-6.6 \%)$, and potassium feldspar $(0-3.0 \%)$. These agree with the results of other studies, showing that quartz and clays are the most common minerals in the Jiaoshiba shales [47]. In general, quartz content in our samples decreases from the bottom to top Longmaxi Formation 


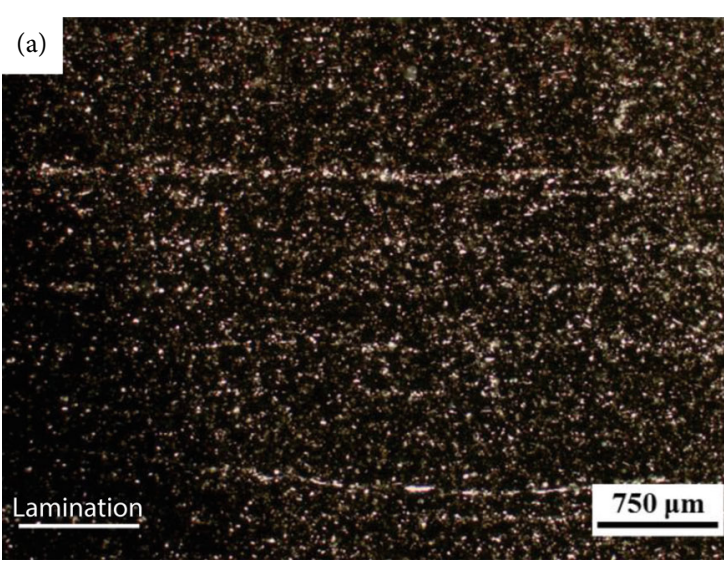

(a)

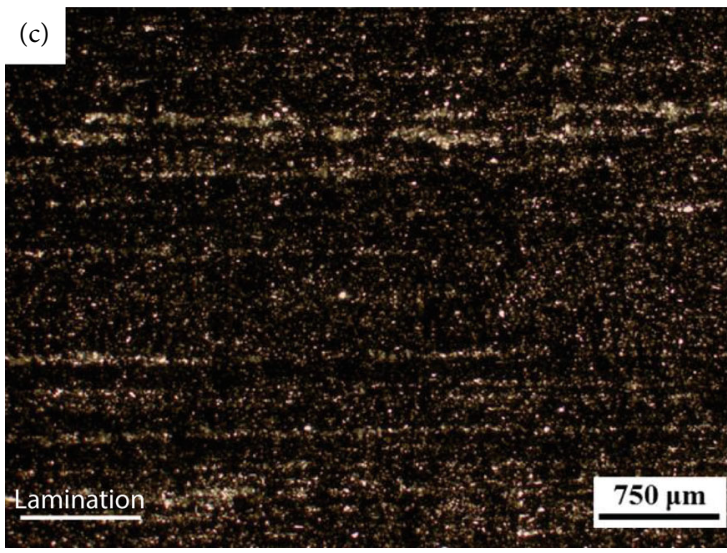

(c)

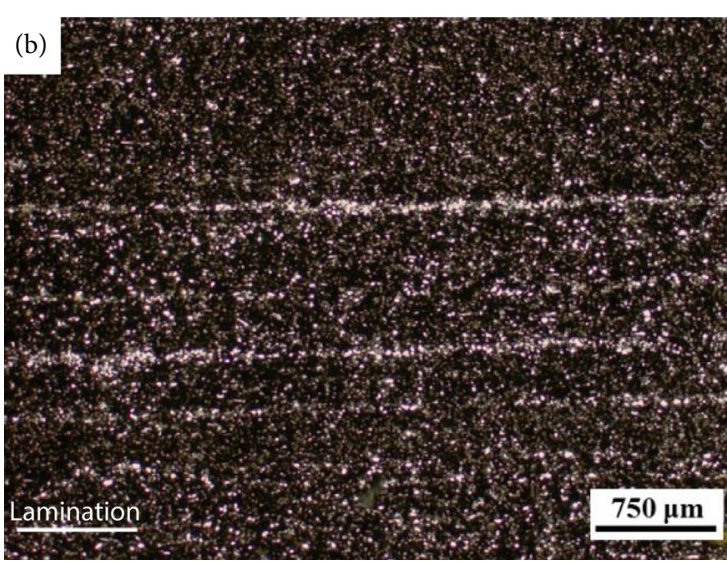

(b)

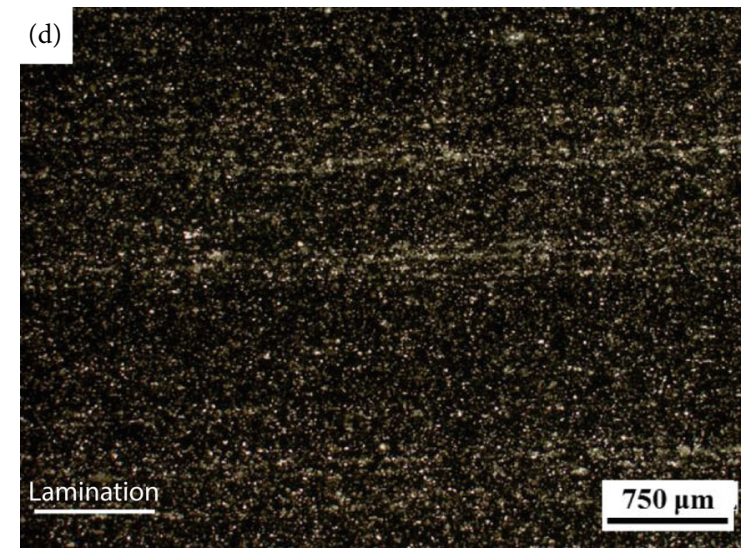

(d)

FIGURE 5: Transmitted light thin section images of argillaceous/siliceous mixed shale lithofacies (M). (a) Laminae of silty quartz. JYA-6, $K_{\mathrm{h}}=25.9 \mu \mathrm{D}$, permeability anisotropy $(\beta)=2.9,2549.19 \mathrm{~m}$. (b) Laminae of silty quartz. JYA- $10, K_{\mathrm{h}}=68.2 \mu \mathrm{D}$, permeability anisotropy $(\beta)$ $=8.9,2563.4 \mathrm{~m}$. (c) Well-laminated fabric. Mixed organic matter and clays distributed between the laminae. JYA-11, $K_{\mathrm{h}}=14.2 \mu \mathrm{D}$, $2569.28 \mathrm{~m}$. (d) Slight laminae of silty quartz. JYA-16, $K_{\mathrm{h}}=11.3 \mu \mathrm{D}, 2593.02 \mathrm{~m}$.

whereas clay minerals present a reverse tend (Table 1). TOC content in our data set ranges from 0.3 to $5.3 \mathrm{wt} . \%$ with a mean value of $2.2 \mathrm{wt} . \%$ (Table 1 ). TOC content is relatively higher in the lower member of Longmaxi Formation. There is a positive correlation between quartz and TOC content (Figure 3). The positive correlation is due to that the quartz in the lower part of Longmaxi Formation is mainly of biogenic origin [20].

4.2. Types of Shales. Lithofacies record geological information about the rock types, texture, bedding, mineral compositions, grain size distribution, and sorting and roundness characteristics [40, 41]. Initially, lithofacies were mainly applied to analyze the mineralogy and petrology of conventional reservoirs [54]. Since the shale gas development is active, lithofacies were introduced to unconventional reservoirs [24, 41]. Shale lithofacies comprehensively describe reservoir characteristics and quality [41]. Based on the mineralogy composition, shales can be divided into siliceous shales (siliceous minerals content $>50 \%$ ), argillaceous/siliceous mixed shales (siliceous, carbonate, and clay minerals content is less than $50 \%$, respectively), and argillaceous shales (total clays content $>50 \%$ ) (Figure 2 and Table 1).
4.2.1. Siliceous Shales. Siliceous shales (S) are mainly found in the lower member of Longmaxi Formation (Table 1). Siliceous shale samples are rich in quartz and relatively low in clay minerals. In siliceous shales, the content of siliceous minerals ranges from $50.3 \%$ to $66.2 \%$ with a mean value of $56.5 \%$. The total clay mineral content ranges from $25.6 \%$ to $38.9 \%$ with an average of $31.9 \%$. Illite-smectite (I/S) mixed clay minerals represent the major components of clay minerals (range from $10.5 \%$ to $19.2 \%$ with an average of $14.5 \%$ ), followed by illite (range from $8.3 \%$ to $16.1 \%$ with an average of $11.7 \%$ ) and chlorite (averages $4.1 \%$ ). Siliceous shale samples are commonly rich in pyrite. Pyrite in siliceous shales exhibits an average of $4.8 \%$ (ranges from $3.8 \%$ to $6.6 \%$ ).

Thin sections of siliceous shales show that the fabric of siliceous shales ranges from faintly laminated to nonlaminated with increasing depth (Figure 4). Abundant radiolarians are observed in siliceous shales (Figure $4(\mathrm{~d})$ ). Some radiolarians are replaced by pyrite. Most of the quartz particles in siliceous shales are silt-sized scale. Clays are dyed by organic matter and scattered in the minerals. Only minor lenticular clay flakes are observed along the lamination (Figure 4(c)). Siliceous shales are TOC-rich. Siliceous shales have TOC content ranging from $2.5 \%$ to $5.3 \%$ (average $3.4 \%$ ). 


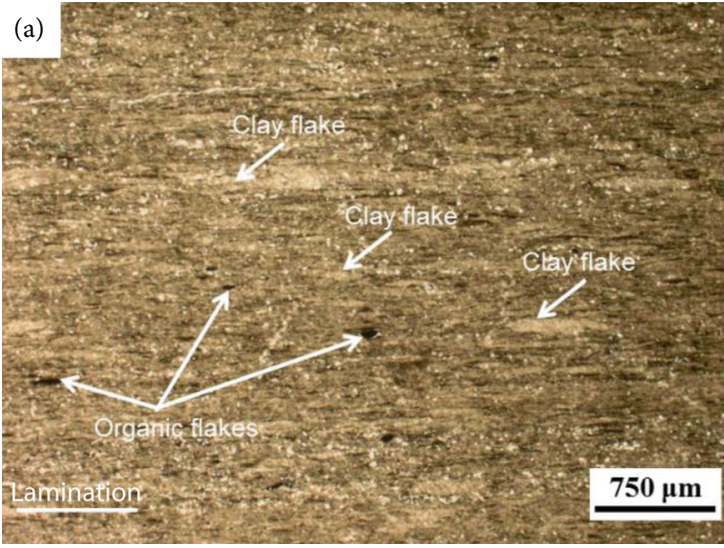

(a)

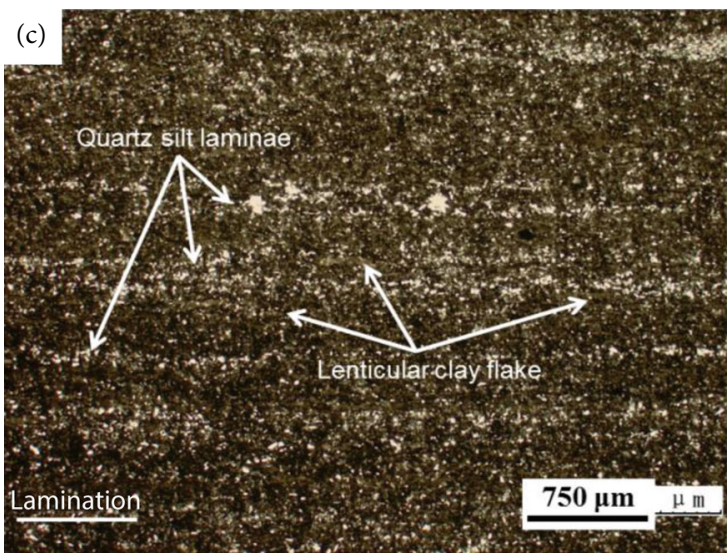

(c)

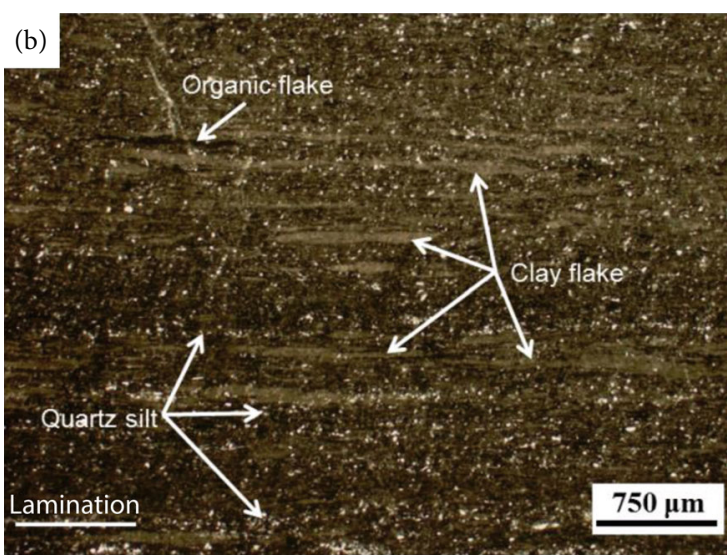

(b)

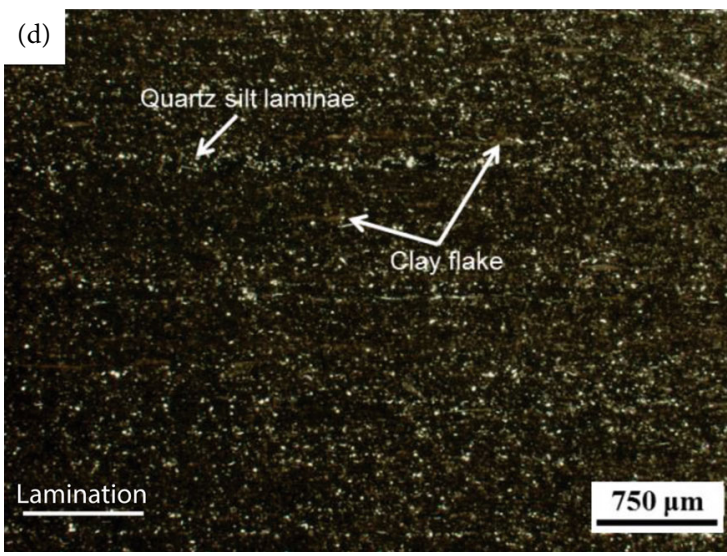

(d)

FIGURE 6: Transmitted light thin section images of silica-rich argillaceous shale lithofacies (CM). (a) Long striped clay flakes distributed along the lamination. Minor organic flakes are intermittent along the lamination. No obvious laminae of silty quartz are observed. JYA-2, $K_{\mathrm{h}}=$ $76.6 \mu \mathrm{D}$, permeability anisotropy $(\beta)=13.4,2531.09 \mathrm{~m}$. (b) Long striped and lenticular clay flakes distributed along the lamination. Organic flake along the lamination is observed. Clay flakes are dyed by organic matters. Minor laminae of silty quartz are intermittently along the lamination. JYA-3, $K_{\mathrm{h}}=64.7 \mu \mathrm{D}$, permeability anisotropy $(\beta)=49.8,2537.09 \mathrm{~m}$. (c) Intermittent laminae of silty quartz. Miniature lenticular clay flakes are along the lamination. JYA-4, $K_{\mathrm{h}}=2.0 \mu \mathrm{D}, 2540.47 \mathrm{~m}$. (d) Slight laminae of silty quartz. Miniature lenticular clay flakes are along the lamination. JYA-8, $K_{\mathrm{h}}=7.8 \mu \mathrm{D}$, permeability anisotropy $(\beta)=10.6,2553.09 \mathrm{~m}$.

4.2.2. Argillaceous/Siliceous Mixed Shales. Argillaceous/siliceous mixed shales $(\mathrm{M})$ are mainly distributed in the middle section of Longmaxi Formation (Table 1). This kind of shales is characterized by the moderate siliceous and clay mineral contents. In this kind of shale lithofacies, siliceous mineral content is between $39.4 \%$ and $47.6 \%$ (averages $44.1 \%$ ), while total clay mineral content varies between $22.7 \%$ and $50.0 \%$ (averages $41.4 \%$ ). Mass contents of I/S mixed clay minerals (averages 16.0\%), illite (averages 12.3\%), and chlorite (averages $11.8 \%$ ) are comparable in mixed shales.

The argillaceous/siliceous mixed shales (M) are well laminated (Figure 5). The laminae mainly consist of silty quartz. The width of laminae ranges from 0.01 to $0.40 \mathrm{~mm}$. Clays in argillaceous/siliceous mixed shales are commonly dyed by organic matter. TOC content of the mixed Longmaxi shales is between $1.4 \%$ and $2.3 \%$ with a mean value of $1.8 \%$.

4.2.3. Argillaceous Shales. The argillaceous shales (CM) are the predominant lithofacies in the upper section of Longmaxi Formation (Table 1). This kind of shales is characterized by the highest content of total clays and the lowest content of quarts. The total clay mineral content in CM shales studied varies from $54.6 \%$ to $62.7 \%$ (averages $58.0 \%$ ), whereas the siliceous mineral content ranges between $37.3 \%$ and $42.7 \%$ (averages 39.8\%). Chlorite is the highest content of clay minerals in CM shales. Chlorite exhibits a mean of $22.4 \%$ (ranges from $18.9 \%$ to $26.3 \%$ ), and I/S mixed clay minerals average $18.6 \%$ (ranges from $15.8 \%$ to $21.2 \%$ ). Slight of pyrite is found in $\mathrm{CM}$ shales (averages $1.6 \%$ ).

Thin sections of CM shales show nonlaminae to intermittent laminae (Figure 6). In argillaceous shales, many long striped and large lenticular clay flakes are oriented along the lamination. Minor organic flakes are also found in CM shales (Figure 6(a)). Quartz is either scattered in the minerals (Figures 6(a) and 6(b)) or exhibits intermittent laminae (Figures 6(c) and 6(d)). TOC content of CM shales is really low and ranges from $0.3 \%$ to $1.7 \%$ (averages $1.0 \%$ ).

4.3. Visual Pore Structure. FE-SEM imaging experiments were conducted on selected Longmaxi shales representing 


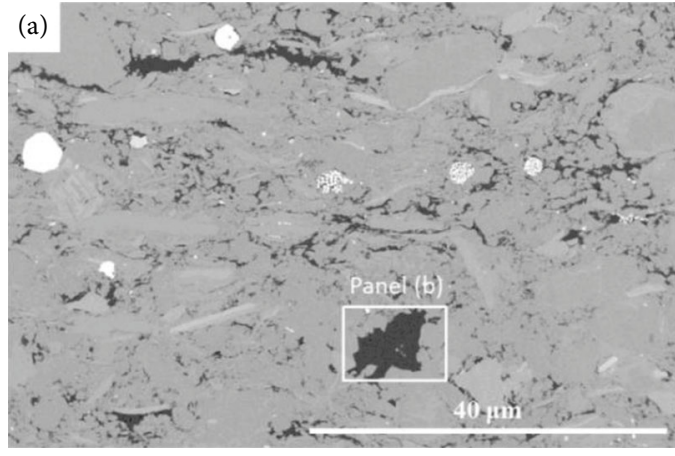

(a)

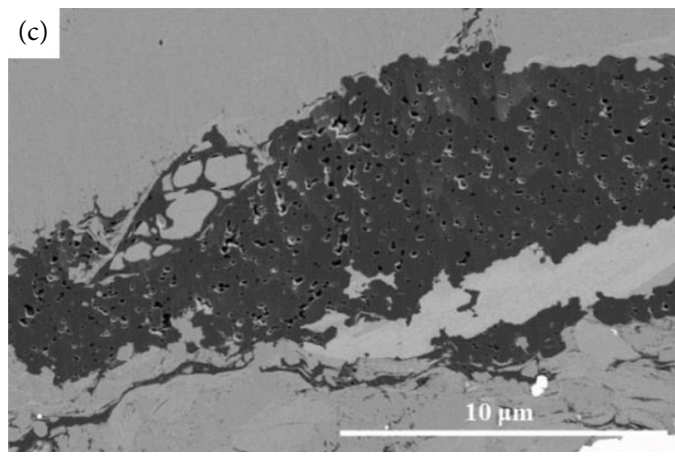

(c)

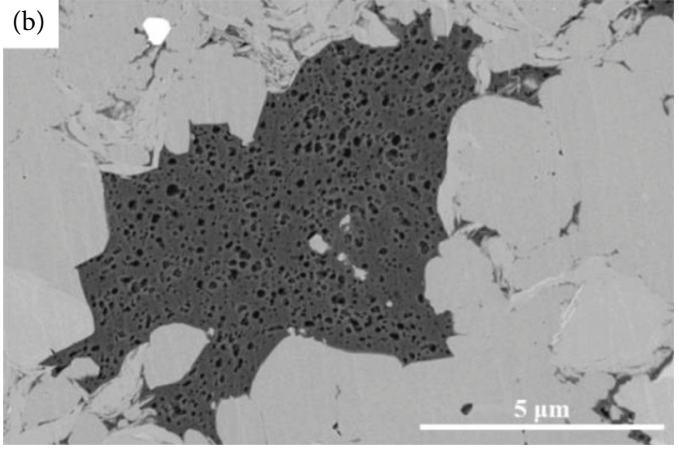

(b)

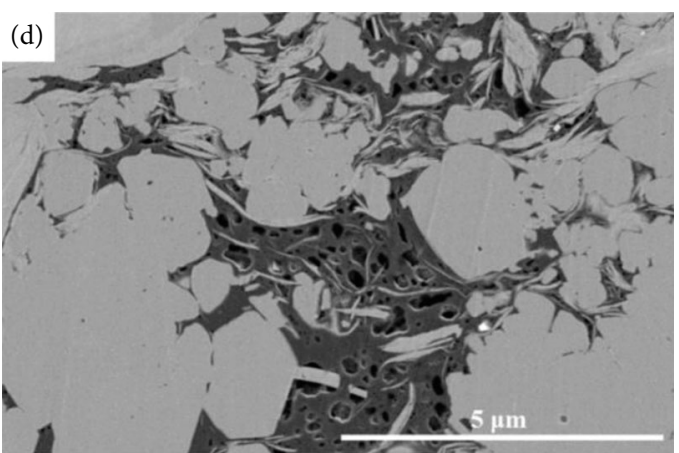

(d)

FiguRE 7: FE-SEM images of siliceous shales (S). (a) Back-scattered electron of siliceous shale lithofacies. (b) Ellipsoid pores in spongy organic matter particles. (c) Abundant pores in spongy organic matter particles. (d) Abundant mesomacropores in organic matter particles.

different kinds of shale lithofacies. Many organic matter (OM) particles in siliceous shales are spongy (Figure 7). The diameter of OM particles varies from several to dozens of micrometers (Figures 7(b) and 7(c)). Among them, abundant OM-hosted pores with a diameter of several to hundreds of nanometers are developed. The OM-hosted pores are commonly elliptoid (Figures $7(\mathrm{c})$ and $7(\mathrm{~d})$ ). A certain amount of irregularly polygonal pores can also be observed in siliceous shales (Figure $7(\mathrm{~d})$ ).

In mixed shales $(\mathrm{M}), \mathrm{OM}$ particles are dispersed and commonly captured in the pore spaces among rigid framework minerals (Figure 8). A handful of OM-hosted pores can be found in these residual organic matters (Figures 8(c) and 8(d)). OM particles with large volume occur in argillaceous/siliceous mixed shales, but pores are less developed in these bulky OM particles (Figure 8(b)). Apparently, these bulky OM particles are difficult to be thermally decomposed or migrated. Dissolution pores are commonly found in argillaceous/siliceous mixed shales (Figures 8(c) and 8(d)). These dissolution pores appear to be so scattered that they are probably less connected. Dissolution-related pores/rims develop among the boundaries of feldspar grains (Figure 8(c)).

When it comes to CM shales, the amount of silty with large particles becomes less than that in mixed shales (M). Clay minerals are really common in the field of vision (Figure 9). Most clay flakes are oriented along the lamination (Figure 9(a)). There are many intraparticle pores in clay flakes, and these pores can be enhanced by bending/splitting related to compaction (Figure 9(c)). A spot of organic matter is captured in the corners of framework minerals (Figure 9(c)). However, these residual organic matters are either nonporous or less porous. Kerogen-clay aggregates are commonly observed and parallel with lamination (Figure 9(d)). However, many pore spaces in kerogen-clay aggregates are unobservable due to strong postcompaction. Large OM particles with smooth surface can be observed occasionally, but OM pores are unobservable in these OM particles under the resolution of FE-SEM (Figure 9(b)).

\subsection{Porosity, Pore Size Distribution, and Pore Structure} Parameters. Porosity of the Longmaxi shales studied ranges from $1.5 \%$ to $7.1 \%$ and averages $3.7 \%$ (Table 2). The porosity values of shale samples are associated with shale lithofacies. Siliceous shales generally show higher porosity values than other shales (Figure 3). Porosity of siliceous shales is between $3.4 \%$ and $7.1 \%$ with an average of $4.9 \%$. Porosity of mixed shales ranges between $1.9 \%$ and $3.3 \%$ (averages 2.4\%), whereas the porosity of argillaceous shales ranges from $1.5 \%$ to $4.3 \%$ (averages $3.1 \%$ ). Positive relationships exist among TOC content, siliceous mineral content, and porosity values of the Longmaxi shales studied (Figure 10).

Low-pressure $\mathrm{N}_{2}$ adsorption-desorption isotherms for the Longmaxi Formation samples are shown in Figure 11. Samples rich in organic matter generally adsorb the high amount of nitrogen. What is more, siliceous shale samples obviously adsorb a higher amount of $\mathrm{N}_{2}$ than other samples (Figure 11(a)). All these Longmaxi shales exhibit hysteresis loops, formed by the divergence between adsorption and 


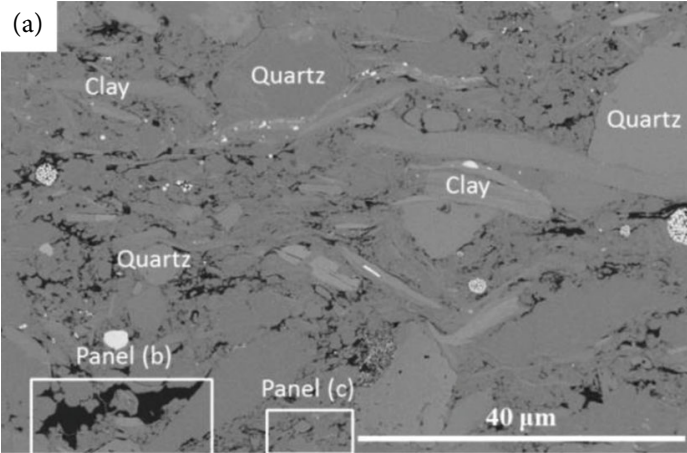

(a)

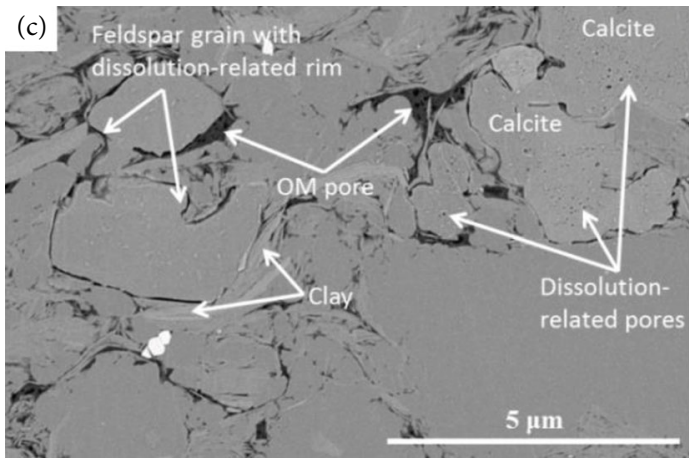

(c)

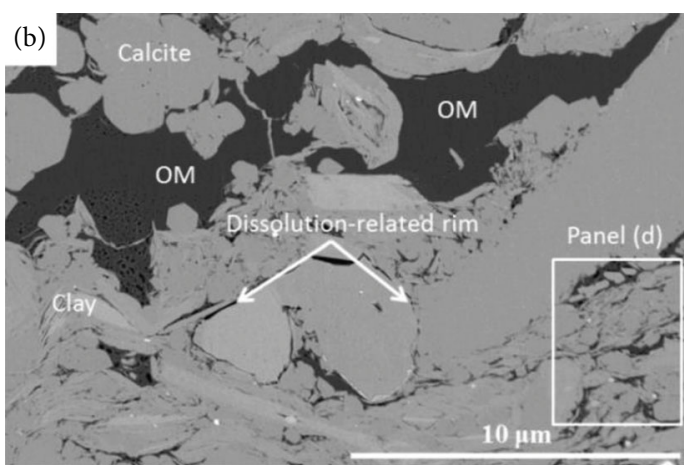

(b)

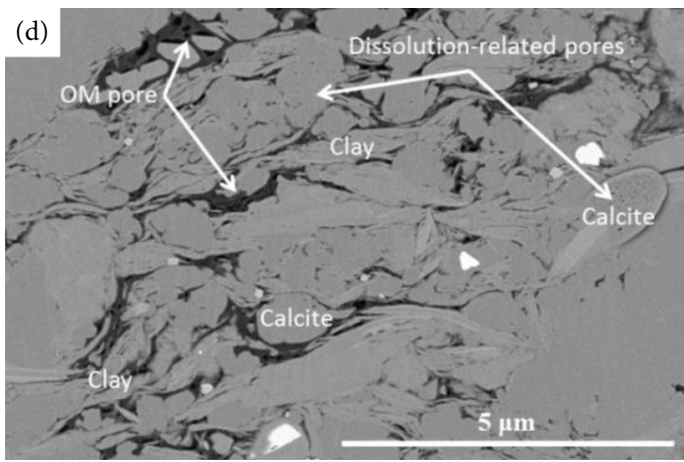

(d)

FIGURE 8: FE-SEM images of argillaceous/siliceous mixed shales (M). (a) Back-scattered electron of argillaceous/siliceous mixed shale lithofacies. There are many silt-sized quartz particles in argillaceous/siliceous mixed shale sample. (b) Large OM particles in argillaceous/siliceous mixed shale, but pores are less developed. (c) Dissolution-related rims in the boundary of feldspar. Dissolutionrelated pores in calcite are less connected. (d) OM-hosted pores in the residual OM particles.

desorption branches. It is interesting to observe that the areas of hysteresis loops on siliceous shales (S) are generally higher than that of mixed $(\mathrm{M})$ and argillaceous shales (CM). According to the physical adsorption theory, the shape of hysteresis loop is associated with the complexity of pore structure [53]. Large hysteresis loops qualitatively indicate that pores of the materials are mainly inkbottle-shaped or amorphous. The pore structure of siliceous shales are much more complicated than other samples, which are probably related with the high TOC content of siliceous shales [16].

The adsorption branches of nitrogen adsorption isotherms were used to calculate the PSD. All the samples exhibit broad PSDs ranging from micropores to mesopores and macropores (Figure 11). PSD of these Longmaxi shales are dominantly bimodal. There is one maximum in the microporous ranges of PSDs. The other maximum is in the $2-3 \mathrm{~nm}$ on the PSDs. Comparing the peaks of different shales, it is found that the first peak in the micropore range of siliceous shales (S) is obviously higher than others, whereas the second peak of mixed (M) and argillaceous shales $(\mathrm{CM})$ is slightly higher than siliceous shales (S).

Pore structure parameters measured by $\mathrm{N}_{2}$ adsorption on the Longmaxi shales are summarized in Table 2. BET-specific surface areas of the Longmaxi shales vary from 9.7 to $26.9 \mathrm{~m}^{2} / \mathrm{g}$, with a mean value $17.0 \mathrm{~m}^{2} / \mathrm{g}$. The total pore volumes vary from 0.011 to $0.033 \mathrm{~cm}^{3} / \mathrm{g}$. Both specific surface areas (SSA) and pore volumes of siliceous Longmaxi shales are higher than those of mixed (M) and argillaceous (CM) Longmaxi shales. The total pore volume of $\mathrm{S}, \mathrm{M}$, and $\mathrm{CM}$ shales averages as $0.023,0.017,0.015 \mathrm{~cm}^{3} / \mathrm{g}$, respectively. TOC content shows obviously positive linear relationships with both the BET SSA and pore volume (Figures 12(a) and 12(b)), indicating that the pore structure of organic-rich marine shales is controlled by organic matter. The intercept of these linear fitting is approximately $9 \mathrm{~m}^{2} / \mathrm{g}$ and $0.01 \mathrm{~cm}^{3} / \mathrm{g}$ (Figures 12(a) and 12(b)), which is related to the inorganic matter. A moderate positive correlation exists between siliceous mineral content and pore structure parameters (Figures 12(c) and 12(d)). Negative relationship exists between clay mineral content and pore structure parameters of the Longmaxi shales (Figures 12(e) and 12(f)).

4.5. Permeability and Permeability Anisotropy. Gas permeability values of overall 29 core plugs were determined. Among them, twenty-one samples were drilled parallel to bedding and eight plugs were perpendicular to bedding. Parallel to bedding, the Klinkenberg-corrected nitrogen permeability (intrinsic permeability) values measured using the pulse-decay permeameter on the confining pressure of 2000 psi ranging from 0.4 to $76.6 \mu \mathrm{D}\left(10^{-18} \mathrm{~m}^{2}\right)$ (Table 2). The Klinkenberg-corrected permeability values measured parallel to bedding $\left(K_{\mathrm{h}}\right)$ of siliceous shales are generally lower than those of other shales. The average $K_{\mathrm{h}}$ of the Longmaxi shales studied decrease in a descending order: argillaceous 


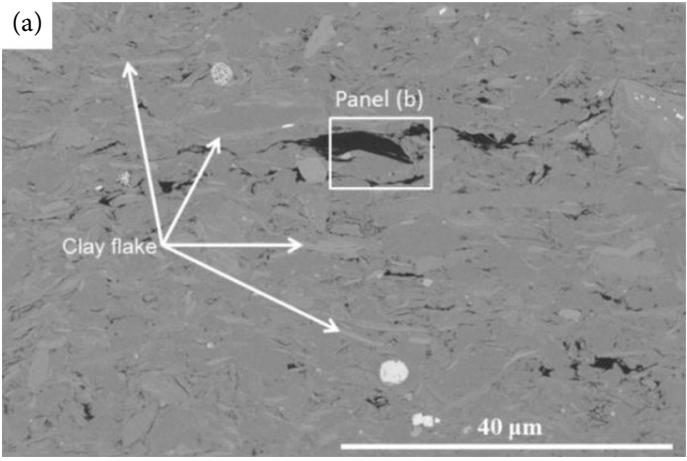

(a)

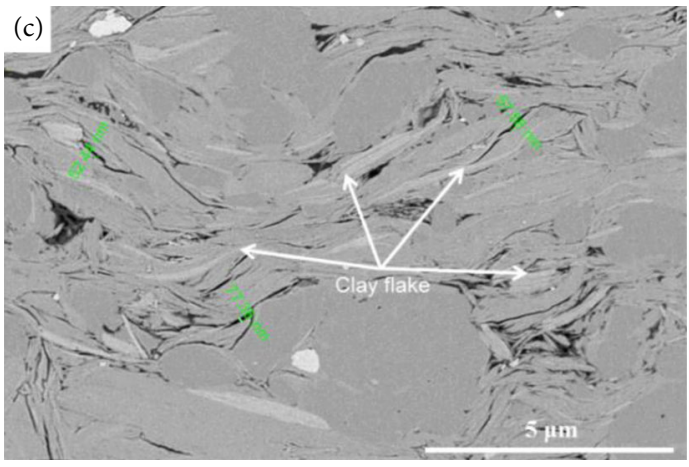

(c)

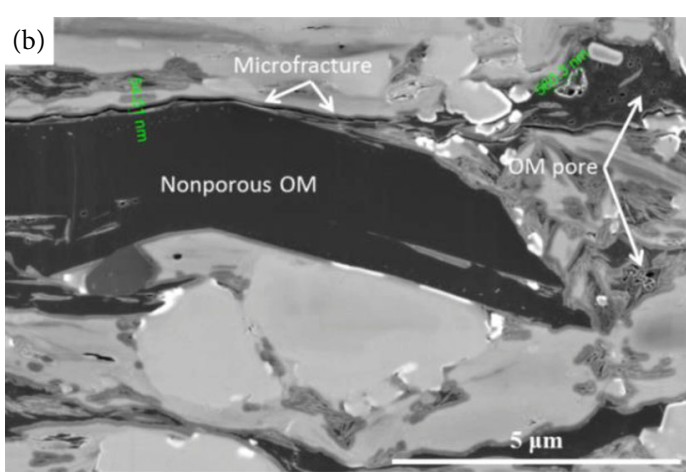

(b)

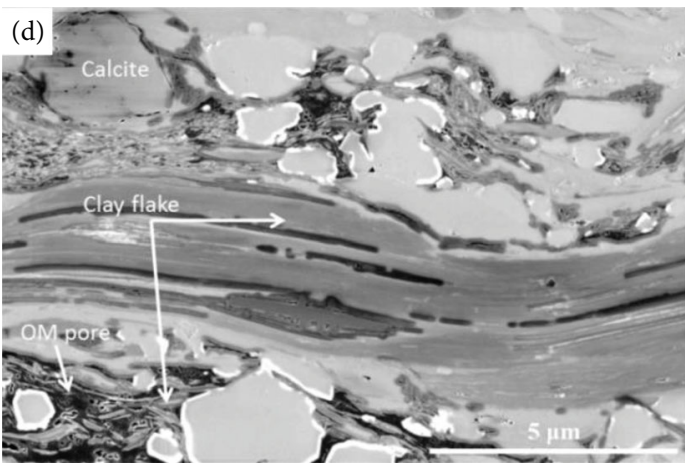

(d)

FIGURE 9: FE-SEM images of silica-rich argillaceous shales (CM). (a) Back-scattered electron of silica-rich argillaceous shales. Abundant clay flakes are commonly oriented along the lamination. (b) Nonporous organic matter particles in silica-rich argillaceous shale. There is microfracture between organic matter particle and framework minerals. (c) Intraparticle pores are observed in clay flakes. (d) Pores in oriented kerogen-clay aggregates.

shales $(37.6 \mu \mathrm{D})>$ mixed shales $(24.4 \mu \mathrm{D})>$ siliceous shales $(8.2 \mu \mathrm{D})$. The permeability measured perpendicular to bed$\operatorname{ding}\left(K_{\mathrm{v}}\right)$ of these samples ranges between 0.3 to $8.9 \mu \mathrm{D}$. Permeability anisotropy values show large variations and range from 1.3 to 49.8 . The permeability anisotropy is related to the fabrics and mineralogy of the samples (Figures 4, 5, and 6 ). The $K_{\mathrm{h}}$ of argillaceous shales are generally more than one order of magnitude higher than that measured perpendicular to bedding (Table 2). Furthermore, samples rich in laminated fabric always show high permeability anisotropy (Figure 4).

Gas slippage factors for nitrogen on these shales range from 0.04 to $0.88 \mathrm{MPa}$. Gas slippage factors of siliceous shales are larger than argillaceous shales. The slippage factors of siliceous minerals range from 0.14 to $0.26 \mathrm{MPa}$, while those of argillaceous shales are between 0.07 to $0.14 \mathrm{MPa}$.

\section{Discussion}

5.1. The Effect of Minerals and Microfabric on Pore Structure. Mineralogical controls on pore spaces have been extensively investigated on both marine and lacustrine shales [12, 16]. Generally, there is a positive correlation between porosity and TOC content of many mature and overmature shale systems [16]. Similarly, porosity of the Longmaxi shales in our data set is positively related to TOC content. The average porosity related to inorganic matter is estimated as $1.7 \%$ according to the interception of the linear relationship (Figure 10(a)). The positive correlation between TOC content and porosity of Longmaxi shales studied underlines the key role of organic matter on pore spaces of overmatured marine shales. With increasing TOC content, peaks in the microporous range in PSD of Longmaxi shales are higher (Figure 11(b)). TOC content also shows an obviously positive relationship with BET SSA of Longmaxi shales studied (Figure 12(a)).

Further investigations reveal that porosity of shale samples is associated with the types of shales. Porosity of siliceous shales (averages 4.9\%) is commonly larger than mixed shales (averages 2.4\%) and argillaceous shales (averages $3.1 \%$ ) (Table 2 ). High porosity values of siliceous shales (S) are ascribed to high TOC content (Figure 7). However, inorganic matter contributes a lot to the pore space of mixed shales (M) and argillaceous shales (CM). For argillaceous/siliceous mixed shales, dissolution-related porosity is commonly observed in feldspars and carbonates. Dissolutionrelated pores occur as intraparticle pores in feldspars and carbonate grains or interparticle pores at the rims of carbonates (Figure 8 ). This kind of pore mainly forms by the dissolution of organic acidic during the process of hydrocarbon generation $[15,16]$. Moreover, silty quartz and carbonates occur in laminae as clasts (Figure 5) and serve as rigid skeleton to support matrix. Interparticle pores exist between soft organic matter and rigid clasts (Figure 8). These kinds 
TABLE 2: Pore structure, porosity, permeability, and permeability anisotropy $(\beta)$ of the shale samples.

\begin{tabular}{|c|c|c|c|c|c|c|c|c|c|c|c|}
\hline Sample & Lithofacies & $\begin{array}{c}\text { Porosity } \\
\text { (\%) }\end{array}$ & $\begin{array}{l}\text { BET SSA } \\
\left(\mathrm{m}^{2} / \mathrm{g}\right)\end{array}$ & $\begin{array}{c}\text { Pore } \\
\text { volume } \\
(\mathrm{mL} / \mathrm{g})\end{array}$ & $\begin{array}{c}\text { Pore } \\
\text { diameter }^{\mathrm{a}} \\
(\mathrm{nm})\end{array}$ & $\begin{array}{c}K_{\mathrm{h}} \\
(\mu \mathrm{D})\end{array}$ & $\begin{array}{c}K_{\mathrm{V}} \\
(\mu \mathrm{D})\end{array}$ & $\begin{array}{c}\text { Permeability } \\
\text { anisotropy }(\beta)\end{array}$ & $\begin{array}{c}\text { Slippage } \\
\text { factor } \\
(\mathrm{MPa})\end{array}$ & $\begin{array}{l}\text { Transport pore } \\
\text { diameter }^{\mathrm{b}}(\mathrm{nm})\end{array}$ & $\begin{array}{l}2 r_{p 35}{ }^{\mathrm{c}} \\
(\mathrm{nm})\end{array}$ \\
\hline JYA-1 & $\mathrm{CM}$ & 2.1 & 10.1 & 0.0115 & 4.5 & 22.13 & - & - & 0.05 & 569 & 686 \\
\hline JYA-2 & $\mathrm{CM}$ & 1.5 & 9.7 & 0.0114 & 4.7 & 76.64 & 5.70 & 13.4 & 0.04 & 787 & 1386 \\
\hline JYA-3 & $\mathrm{CM}$ & 2.0 & 12.7 & 0.0133 & 4.2 & 64.70 & 1.30 & 49.8 & 0.04 & 826 & 1133 \\
\hline JYA-4 & $\mathrm{CM}$ & 4.2 & 14.0 & 0.0151 & 4.3 & 2.04 & - & - & 0.14 & 218 & 172 \\
\hline JYA-5 & $\mathrm{CM}$ & 4.3 & 14.1 & 0.0161 & 4.5 & 52.10 & - & - & 0.05 & 589 & 732 \\
\hline JYA-6 & $\mathrm{M}$ & 2.1 & 18.5 & 0.0190 & 4.1 & 25.92 & 8.90 & 2.9 & 0.12 & 269 & 740 \\
\hline JYA-7 & $\mathrm{CM}$ & 4.3 & 16.4 & 0.0178 & 4.3 & - & - & - & - & - & - \\
\hline JYA-8 & $\mathrm{CM}$ & 3.5 & 17.4 & 0.0186 & 4.3 & 7.76 & 0.73 & 10.6 & 0.10 & 322 & 342 \\
\hline JYA-9 & M & 3.3 & 14.5 & 0.0169 & 4.6 & 1.17 & - & - & 0.39 & 80 & 150 \\
\hline $\begin{array}{l}\text { JYA- } \\
10\end{array}$ & M & 1.9 & 15.0 & 0.0171 & 4.5 & 68.20 & 7.63 & 8.9 & 0.03 & 983 & 1186 \\
\hline $\begin{array}{l}\text { JYA- } \\
11\end{array}$ & M & 3.0 & 11.9 & 0.0150 & 5.0 & 14.22 & - & - & 0.13 & 246 & 481 \\
\hline $\begin{array}{l}\text { JYA- } \\
12\end{array}$ & M & 2.4 & 18.7 & 0.0213 & 4.5 & 25.35 & - & - & 0.07 & 463 & 690 \\
\hline $\begin{array}{l}\text { JYA- } \\
13\end{array}$ & S & 4.3 & 18.9 & 0.0211 & 4.5 & 7.53 & - & - & 0.16 & 256 & 307 \\
\hline $\begin{array}{l}\text { JYA- } \\
14\end{array}$ & S & 5.0 & 20.6 & 0.0223 & 4.3 & 7.01 & - & - & 0.26 & 158 & 276 \\
\hline $\begin{array}{l}\text { JYA- } \\
15\end{array}$ & S & 5.4 & 21.2 & 0.0244 & 4.6 & 10.96 & - & - & 0.14 & 305 & 326 \\
\hline $\begin{array}{l}\text { JYA- } \\
16\end{array}$ & M & 1.9 & 10.8 & 0.0117 & 4.3 & 11.25 & - & - & 0.10 & 315 & 532 \\
\hline $\begin{array}{l}\text { JYA- } \\
17\end{array}$ & $S$ & 3.9 & 16.1 & 0.0196 & 4.9 & 24.41 & - & - & 0.14 & 294 & 545 \\
\hline $\begin{array}{l}\text { JYA- } \\
18\end{array}$ & $S$ & 3.4 & 18.4 & 0.0218 & 4.7 & 14.95 & 1.60 & 9.3 & 0.14 & 290 & 466 \\
\hline $\begin{array}{l}\text { JYA- } \\
19\end{array}$ & S & 4.0 & 18.7 & 0.0210 & 4.5 & 1.09 & - & - & 0.37 & 111 & 133 \\
\hline $\begin{array}{l}\text { JYA- } \\
20\end{array}$ & $S$ & 4.4 & 18.7 & 0.0196 & 4.2 & 4.77 & 1.38 & 3.5 & 0.25 & 169 & 248 \\
\hline $\begin{array}{l}\text { JYA- } \\
21\end{array}$ & S & 7.1 & 21.5 & 0.0229 & 4.3 & 2.33 & - & - & 0.34 & 120 & 145 \\
\hline $\begin{array}{l}\text { JYA- } \\
22\end{array}$ & S & 5.8 & 26.8 & 0.0334 & 5.0 & 0.40 & 0.30 & 1.3 & 0.51 & 81 & 71 \\
\hline $\begin{array}{l}\text { JYA- } \\
23\end{array}$ & $\mathrm{~S}$ & 5.9 & 26.9 & 0.0254 & 3.7 & - & - & - & - & - & - \\
\hline
\end{tabular}

${ }^{a}$ The average pore diameter was determined by low-pressure $\mathrm{N}_{2}$ adsorption analysis. ${ }^{\mathrm{b}}$ The transport pore diameter was derived from gas slippage measurement on parallel to bedding samples. ${ }^{\circ}$ The dominant pore-throat aperture $\left(r_{p 35}\right)$ was estimated using the Winland equation [59].

of interparticle pores occur as preferable transport pathways for bitumen and gas.

Argillaceous shales have specific microfabrics. In argillaceous shales, clay minerals are deformed (Figure 9(c)). Intraparticle pores are situated along cleavage planes of clay flakes and enhanced by bending/splitting related to compaction. Interparticle pores also exist between soft clay flakes and rigid clasts (Figure 9(c)). The inorganic-porosity seems to be reflected in the PSD. The peaks in $2-3 \mathrm{~nm}$ range of mixed (M) and argillaceous shales (CM) are higher than those of siliceous shales (Figures 11(b), 11(d), and 11(f)), which is likely contributed by clay minerals [55].
Linear combination is a useful tool to quantitatively assess the petrophysical properties of rocks [12, 25]. Total porosity of shales can be viewed as the sum of porosity values related to OM, framework minerals, and total clay minerals:

$\phi=\rho_{\text {bulk }} \cdot\left[w_{\text {TOC }} \cdot \bar{v}_{\text {OM }}+w_{\text {Framework }} \cdot \bar{v}_{\text {Framework }}+w_{\text {Clay }} \cdot \bar{v}_{\text {Clay }}\right]$

Here, $w_{\mathrm{OM}}, w_{\text {Framework }}$, and $w_{\text {Clay }}$ are the mass fractions of OM, framework minerals (quartz, carbonates, pyrite, etc.), and total clays, respectively; $\bar{v}_{\mathrm{OM}}, \bar{v}_{\text {Framework, }}$ and $\bar{v}_{\text {Clay }}$ 


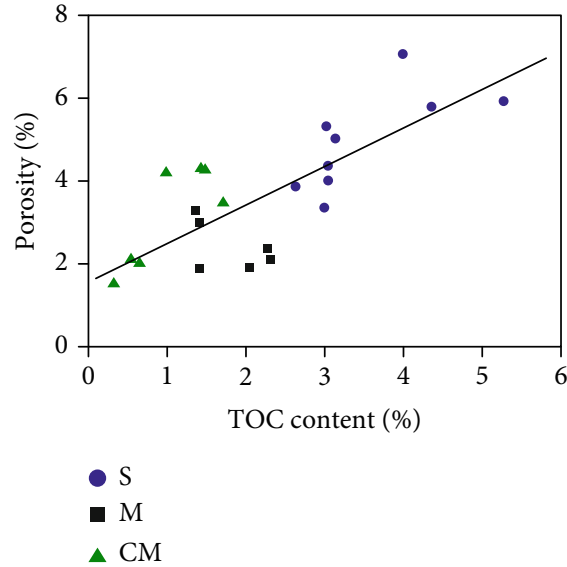

(a)

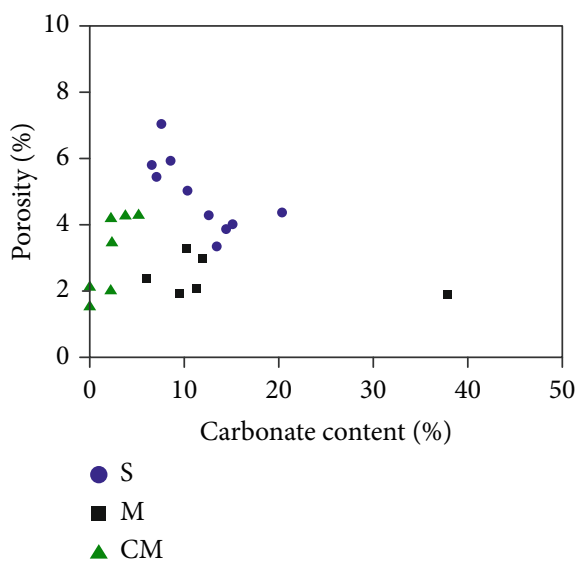

(c)

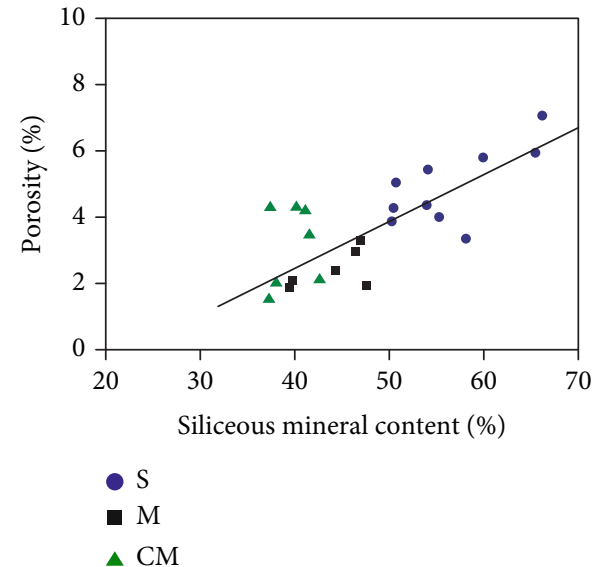

(b)

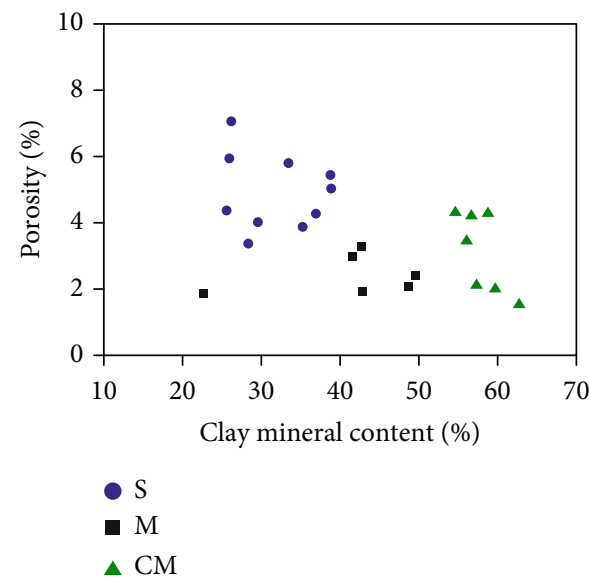

(d)

FIGURE 10: Relationship between porosity and (a) TOC content, (b) siliceous minerals content, (c) carbonate content, and (d) clay minerals content of shale samples.

$\left(\mathrm{cm}^{3} / \mathrm{g}\right)$ are the pore volume of organic matter, framework minerals, and total clays, normalized to the mass of rock, respectively.

The bulk density $\left(\rho_{\text {bulk }}\right)$ and porosity $(\phi)$ values can be determined from helium pycnometry measurements, while the mass fractions of individual mineral components can be obtained from XRD analysis. Thus, there are three unknown parameters (specific pore volumes $\bar{v}_{\text {OM }}, \bar{v}_{\text {Framework }}$, and $\bar{v}_{\text {Clay }}$ ) in the physical model, which can be simultaneously solved using a multielement nonlinear regression on a suit of shale samples. The fitted $\bar{v}_{\mathrm{OM}}, \bar{v}_{\text {Framework }}$, and $\bar{v}_{\text {Clay }}$ of the Longmaxi shales is $0.4534 \mathrm{~cm}^{3} / \mathrm{g}, \quad 0.0002 \mathrm{~cm}^{3} / \mathrm{g}$, and $0.0124 \mathrm{~cm}^{3} / \mathrm{g}$, respectively. Consequently, the organic matter-hosted pores account for $79 \%$ of the total porosity while clay minerals pores account for $20 \%$ of total porosity in siliceous shales (Figure 13). In mixed shales, organic matter-hosted pores account for $62 \%$ while the pore spaces associated with clay minerals account for $38 \%$ of the total porosity. Argillaceous shales are dominant by pores associated with clay minerals. In argillaceous shales, clay minerals account for $62 \%$ of the total porosity while the OM-hosted pores account for $37 \%$. It should be noted that the linear combination method pro- vides fast and semiquantitative characterization of pore spaces. The effects of mineralogy on porosity and pore space of rocks are much more complicated and associated to the interaction between organic and inorganic matters. The contribution of organic matter to porosity of argillaceous shales is probably an optimistic value since it is difficult to find lots of OM-hosted pores in argillaceous shales (Figure 9).

5.2. The Effect of Microfabric and Laminae on Permeability and Permeability Anisotropy. Shale permeability is related to many geological controls: including fabric, texture, lithology, porosity, and pore size distribution [20,38]. Geological controls on permeable property of tight shales are always rock specific. In Devonian gas shales from the Horn River and Liard Basins of Canada, high matrix permeability shales were found to contain connected transport pathways between macropores and micropores [20]. Gas shales containing balanced ratio of micro-, meso- and macropores have higher matrix permeability values. Yang and Aplin [21] analyzed the effect of lithology on permeability of deeply buried mudstones and found that coarser-grained mudstones always have higher permeability values than finer-grained 


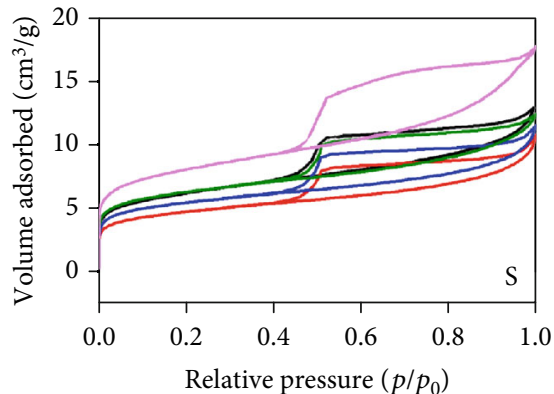

Relative pressure $\left(p / p_{0}\right)$

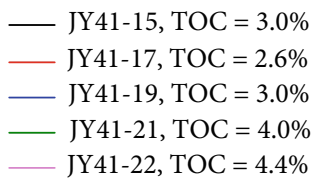

(a)

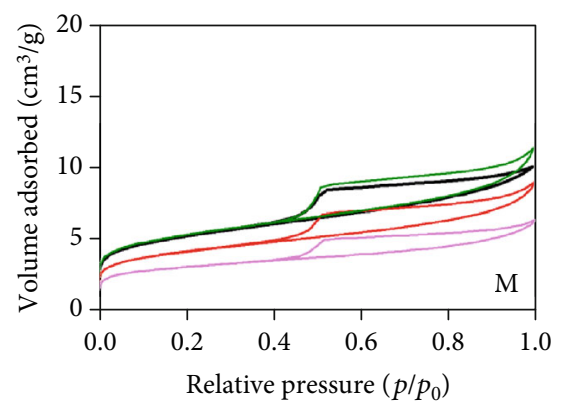

JY41-6, TOC $=2.3 \%$

- JY41-9, TOC $=1.4 \%$

- JY41-12, TOC $=2.3 \%$

- JY41-16, TOC $=1.4 \%$

(c)

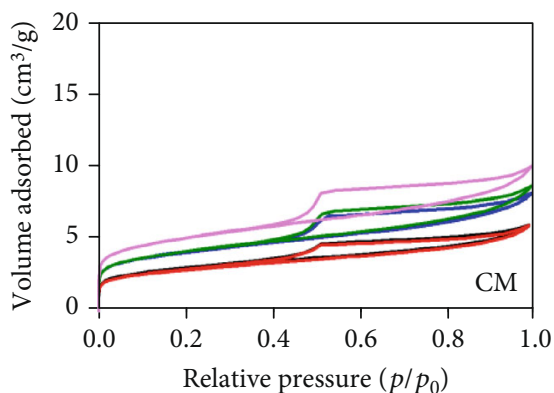

Relative pressure $\left(p / p_{0}\right)$

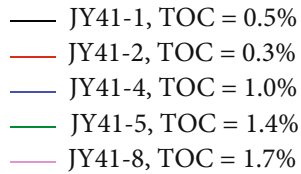

(e)
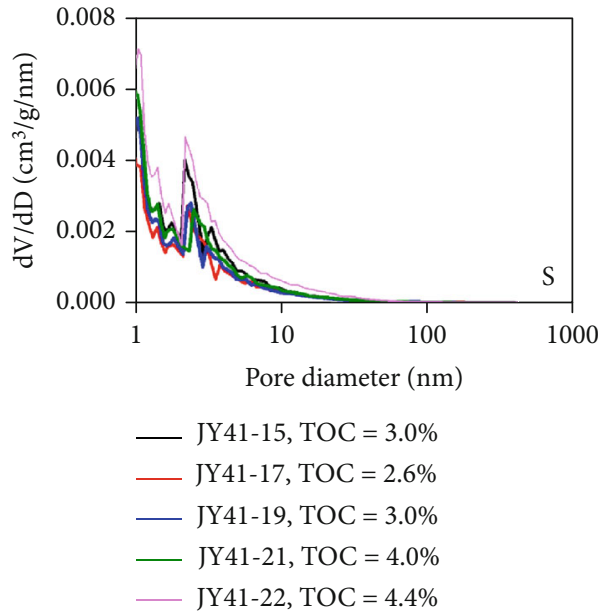

(b)
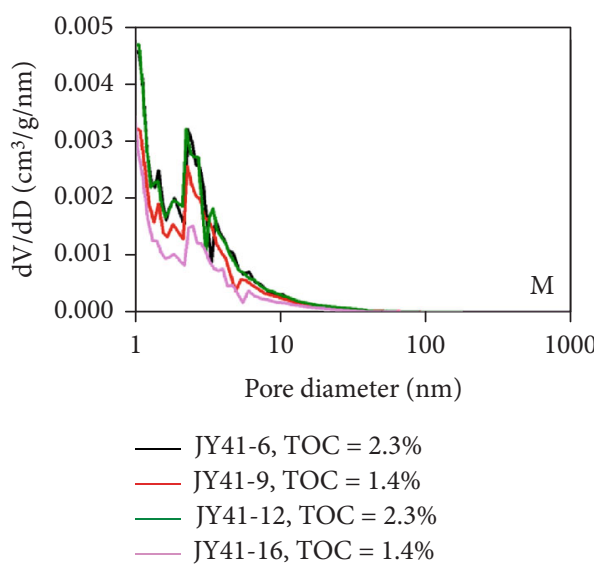

(d)

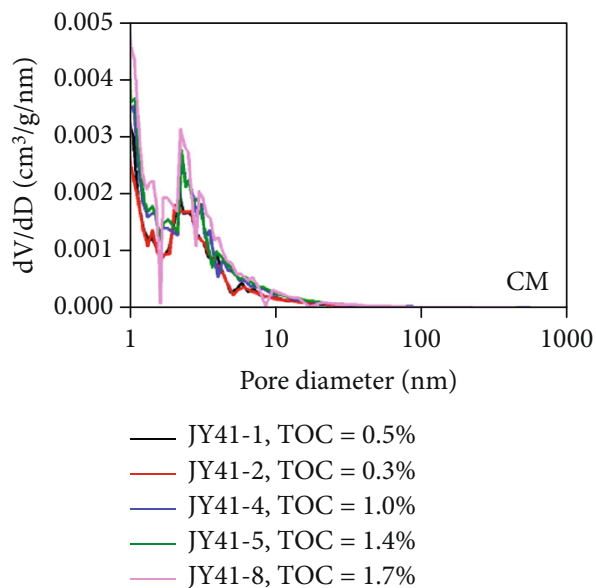

(f)

FIGURE 11: Low-pressure nitrogen adsorption isotherms and of pore size distributions of shale samples. (a, b) Siliceous shale lithofacies (S); (c, d) argillaceous/siliceous/calcareous mixed shale lithofacies (M); (e, f): silica-rich argillaceous shale lithofacies (CM).

mudstones. However, permeable property of Longmaxi shales in our data set is mainly associated with the fabric and laminae instead of pore-size distributions. Though the porosity of mixed shales $(\mathrm{M})$ and argillaceous shales $(\mathrm{CM})$ is lower than that of siliceous shales $(\mathrm{S})$, the average $K_{\mathrm{h}}$ values of argillaceous shales $(37.6 \mu \mathrm{D})$ and mixed shales $(24.4 \mu \mathrm{D})$ are obviously larger than those of siliceous shales $(8.2 \mu \mathrm{D})$. The reason for that is that the clay flakes and the microlaminae of clasts oriented to the lamination/bedding noticeably influence the permeabilities $\left(K_{\mathrm{h}}\right)$ of these Longmaxi shales 


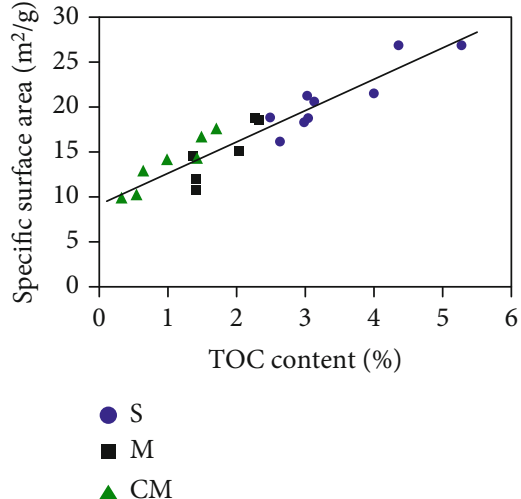

(a)

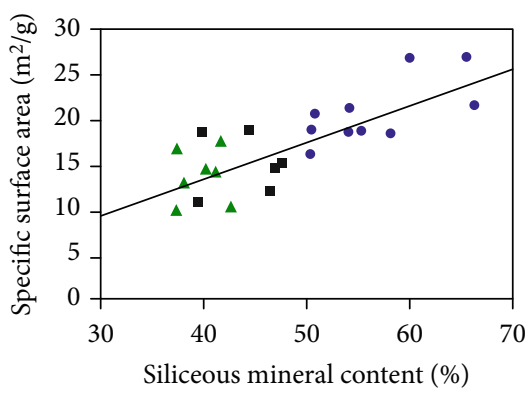

- $\mathrm{S}$

- $\mathrm{M}$

A $\mathrm{CM}$

(c)

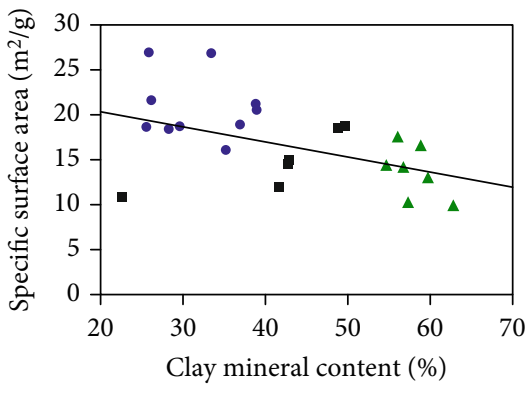

- $\mathrm{S}$

- $\mathrm{M}$

\ $\mathrm{CM}$

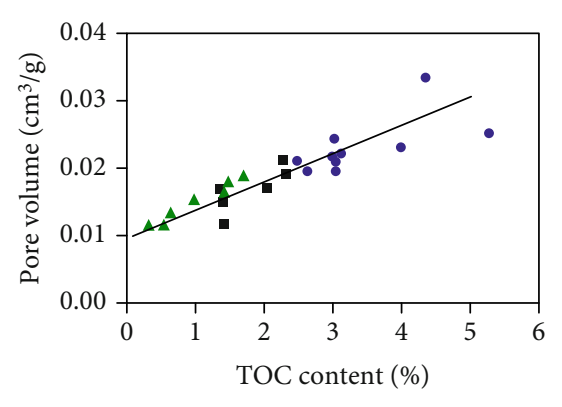

- $\mathrm{S}$

- $\mathrm{M}$

$\Delta \mathrm{CM}$

(b)

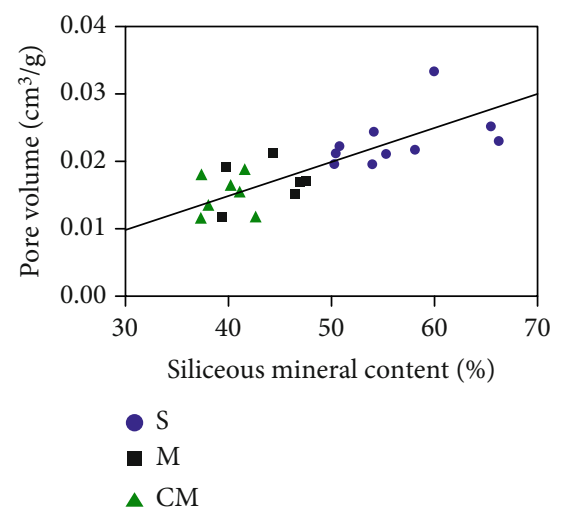

(d)

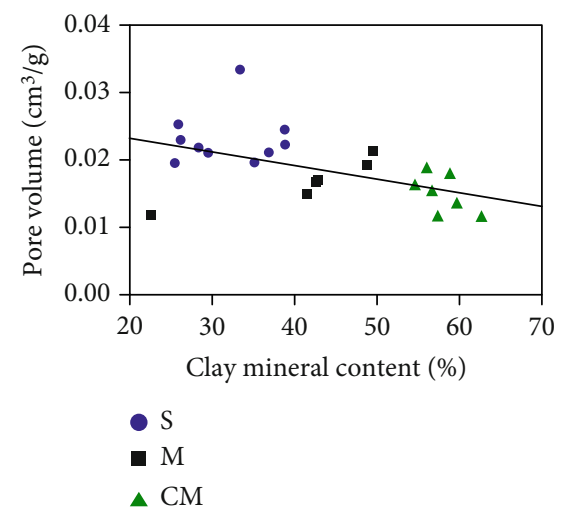

(f)

FIGURE 12: The relationship between (a) TOC content and specific surface area, (b) TOC content and total pore volume, (c) siliceous mineral content and specific surface area, (d) siliceous mineral content and pore volume, (e) clay mineral content and specific surface area, and (f) clay mineral content and pore volume of shale samples.

studied (Figures 5 and 6). Intraparticle pores of oriented clay minerals and interparticle pores between rigid clast particles and soft minerals (clay minerals or OM) are commonly distributed along the lamination/bedding of argillaceous shales and mixed shales (Figures 8 and 9). Though the inorganic matter-related porosity is less than OM-hosted porosity, the intraparticle pores in clay minerals and interparticle pores between organic and inorganic minerals play a significant role (preferable pathways) in fluid transport processes. These can be illustrated by the residual bitumen (migrabitumen) captured in these pore spaces among grains (Figures 8(c) and $8(\mathrm{~d})$ and Figure 9(c)). Conversely, siliceous shales at the bottom of Longmaxi Formation are mainly formed in euxinic sediment environment [48, 49]. Siliceous shales in Longmaxi Formation are obviously less in laminae compared to mixed and argillaceous shales (Figure 4). In siliceous shales, a lot of spongy organic matter are distributed without any preferred direction in the vision of SEM (Figure 7). What is more, permeabilities $\left(K_{\mathrm{h}}\right)$ of siliceous shales with faint laminae (JYA-17, JYA-18) are also higher than nonlaminated 


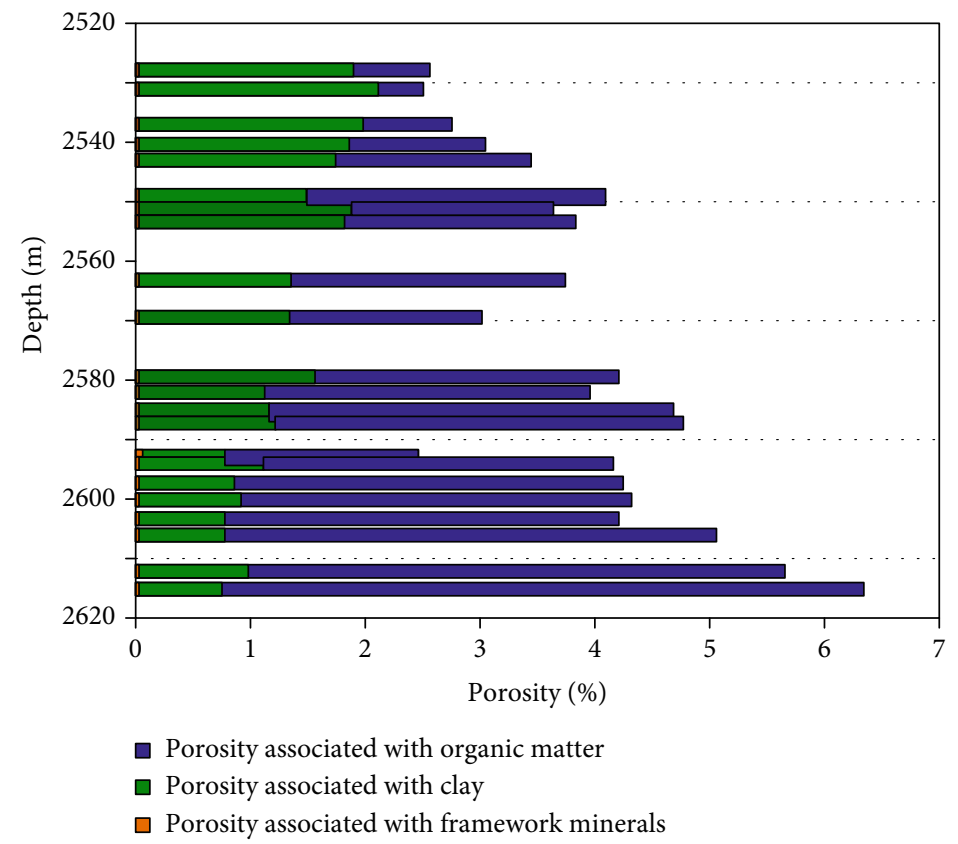

FIGURE 13: The semiquantitative estimation of porosity related to mineralogy using the linear combination approach.

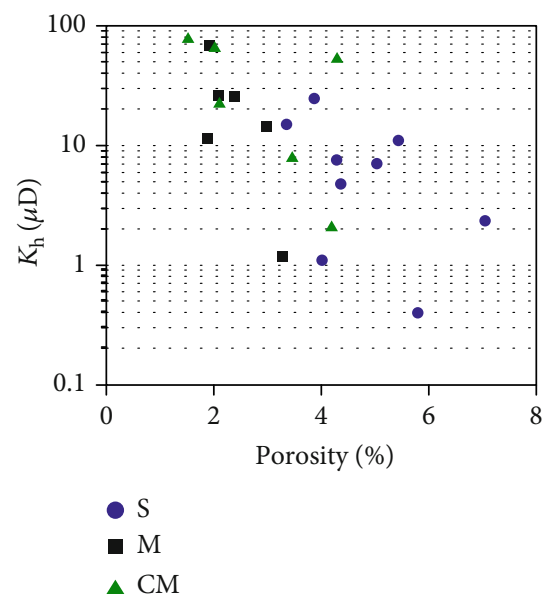

(a)

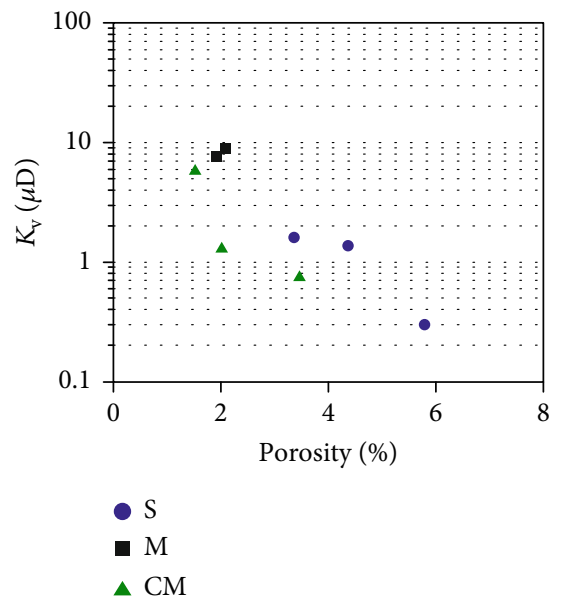

(b)

FIGURE 14: Effect of lithology on the relationship between permeability and porosity. (a) The permeability $\left(K_{\mathrm{h}}\right)$ was measured parallel to bedding. (b) The permeability $\left(K_{\mathrm{v}}\right)$ was measured perpendicular to bedding.

siliceous shales (JYA-22, Figure 4). In a word, TOC content does influence the porosity of these Longmaxi shales but is not the critical factor on permeability.

The porosity-permeability relationships of shales have been assessed in previous investigations. Some investigators reported a power law relationship between porosity and permeability [21]. In this study, there is a weak negative relationship between porosity and permeability coefficients (Figure 14). The fabric and texture highly influence the relationships between porosity and permeability. Though the porosity of siliceous shales is larger than other shales, permeability values of this kind of shales are actually lower. The intraparticle pores of oriented clay minerals and interparticle pores between organic and inorganic matters (microlaminae of clasts) develop in $\mathrm{M}$ and $\mathrm{CM}$ shales (Figures 5 and 6), which contribute to both $K_{\mathrm{h}}$ and $K_{\mathrm{v}}$.

Permeability anisotropy (the ratio of horizontal permeability $K_{\mathrm{h}}$ to vertical permeability $K_{\mathrm{v}}$ ) has been reported on shale systems $[37,56]$. Permeability anisotropy of Longmaxi shales in this study varies from 1.3 to 49.8 (confining pressure of 2000 psi), which is comparable to other shales [37]. Permeability anisotropy is related to the pores with oriented alignment, permeable layers, and preferable migration pathway of shales. In this study, permeability anisotropy of argillaceous shales is higher than that of siliceous shales (Figure 15). The permeability anisotropy values of three siliceous shale samples are less than ten, whereas $K_{\mathrm{h}}$ of argillaceous shales are generally higher than $K_{\mathrm{v}}$ more than one order of 


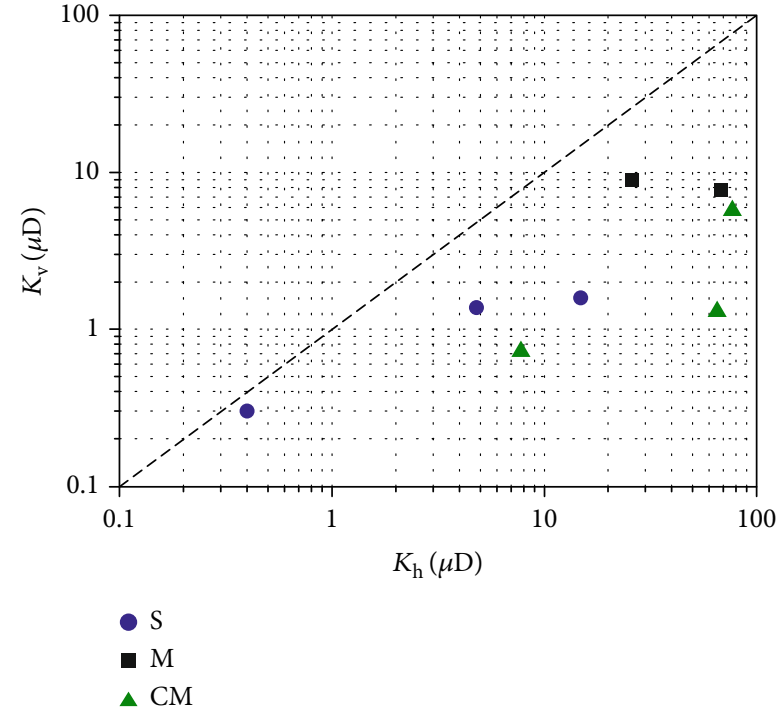

FIGURE 15: Klinkenberg-corrected permeability coefficients measured parallel $\left(K_{\mathrm{h}}\right)$ and perpendicular $\left(K_{\mathrm{v}}\right)$ to bedding.

magnitude. This is probably related to the microfabric of the shales. Abundant clay flakes are oriented to the lamination in argillaceous shales (Figures 6(a) and 6(c)), whereas quartz in siliceous shales is randomly orientated and clays are scattered (Figures 4(a) and 4(d)). Furthermore, samples rich in laminated fabric (sample) always show high permeability anisotropy (Figure 4(b) and Figure 5(b)).

5.3. Effective Transport Pore Diameter of Shales. The effective transport pore diameter can be derived from gas slippage factors during permeability measurements $[19,57]$. By assuming cylindrical pores, the effective transport pore diameter is a function of gas slippage factors using the theory of Klinkenberg [29]:

$$
d=\frac{8 c \lambda P_{m}}{b}
$$

where $d(m)$ is effective pore diameter for gas transport; $c \approx 1$ is the Adzumi constant, $\lambda(m)$ is the gas mean free path, $P_{m}$ $(\mathrm{Pa})$ is mean pore pressure, and $\mathrm{b}(\mathrm{Pa})$ is the gas slippage factor.

Combined with the slippage factors, the effective transport pore diameter for gas transport in the shales parallel to the bedding ranges from 80 to $983 \mathrm{~nm}$ at the experimental confining pressure. These values are much higher than the average pore diameters derived from low-pressure $\mathrm{N}_{2}$ adsorption analysis (Table 2). The pore diameter obtained from low-pressure $\mathrm{N}_{2}$ adsorption analysis is a representation of pore structure of shale matrix, while the pulse-decay permeability is directional and strongly influenced by the occurrence of preferential pathways (laminae or microfractures). The effective transport pore diameter of siliceous shales ranges between 81 and $305 \mathrm{~nm}$ (averaging $191 \mathrm{~nm}$ ), while the effective transport pore diameter of argillaceous shales ranges from 218 to $826 \mathrm{~nm}$ (averaging $552 \mathrm{~nm}$ ). There is a negative correlation between TOC content and effective transport pore diameters of the shales studied (Figure 16(a)), while a positive correlation exists between clay mineral content and effective transport pore diameters of shale samples (Figure 16(b)). This further implies that there are developed preferred transport paths in argillaceous shales. Through comparison with the visual pore structure characteristics, it is thought that the intraparticle pores between the oriented minerals are the preferential transport pathways.

The Winland equation, originally developed from mercury intrusion capillary pressure (MICP) measurements of conventional reservoir rocks, was recently used to identify the flow unit and estimate the dominant pore throat diameters for fluid flow in shales [58]. Though the Winland equation is an empirical method based on MICP data, it provides visual information about the pore diameter and permeability. The Winland equation describing the rock permeability $(\mathrm{mD})$, porosity (decimal), and $r_{p 35}$ (dominant porethroat aperture, $\mu \mathrm{m})$ can be written as $[58,59]$

$$
r_{p 35}=2.665\left[\frac{k}{100 \phi}\right]^{0.45} .
$$

Using the permeability and porosity values, the dominant pore throat diameter $\left(2 r_{p 35}\right)$ for fluid transport estimated from the Winland method ranges from 71 to $1386 \mathrm{~nm}$ (Table 2). These values are slightly larger than those estimated from gas slippage measurements, which is probably related to the difference of tortuosity in shales and the conventional reservoir rocks. However, both these two methods show that the effective transport pore diameters of siliceous shales are commonly lower than those of argillaceous shales (Figure 17). The dominated pore-throat diameter of siliceous shales lies between 50 and $300 \mathrm{~nm}$, while that of argillaceous shales is between 100 and $1000 \mathrm{~nm}$. These values underline the controls of microfabric and texture on transport pathways of Longmaxi shales.

\section{Conclusions}

Comprehensive investigations on reservoir characteristic of Longmaxi shales from a shale gas well in the Jiaoshiba area, Sichuan Basin, were conducted. Special attentions were focused on the effects of microfabric and laminae on pore structure and gas transport pathways of shales. The following conclusions can be drawn:

(1) In general, there are three different kinds of lithofacies in the Longmaxi Formation: faintly laminated to nonlaminated siliceous shales (S), laminated mixed shales (M), and argillaceous shales (CM) with oriented clay flakes. Porosity of these Longmaxi shales studied is positively correlated with TOC content and ranges from 1.5 to $7.1 \%$. Organic matter approximately contributes $79 \%$ to the pore spaces of siliceous shale samples, whereas interparticle pores related to inorganic matter contribute $63 \%$ to the pore spaces of argillaceous shale samples 


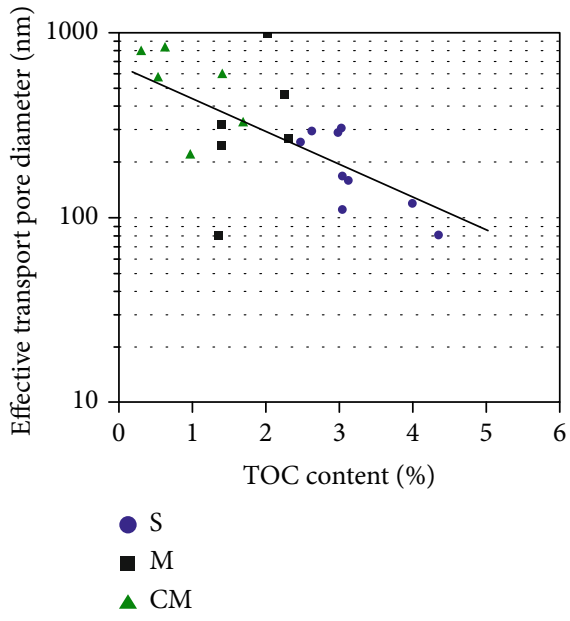

(a)

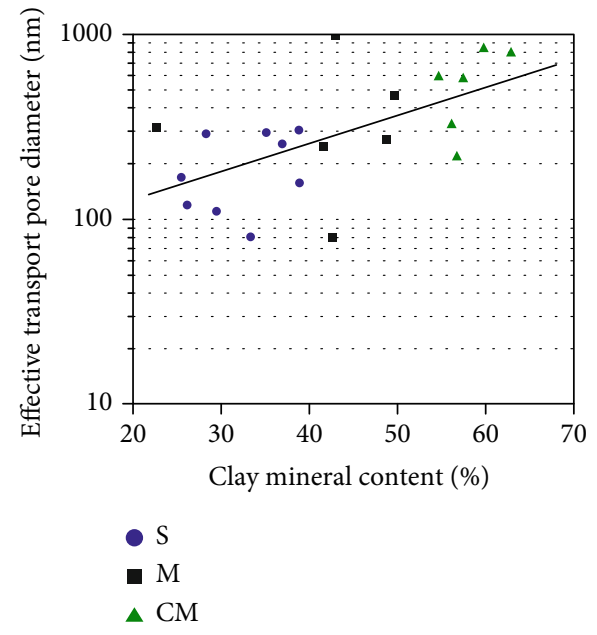

(b)

FIgURE 16: The relationship between (a) TOC content, (b) clay mineral content, and transport pore diameter of shale samples.

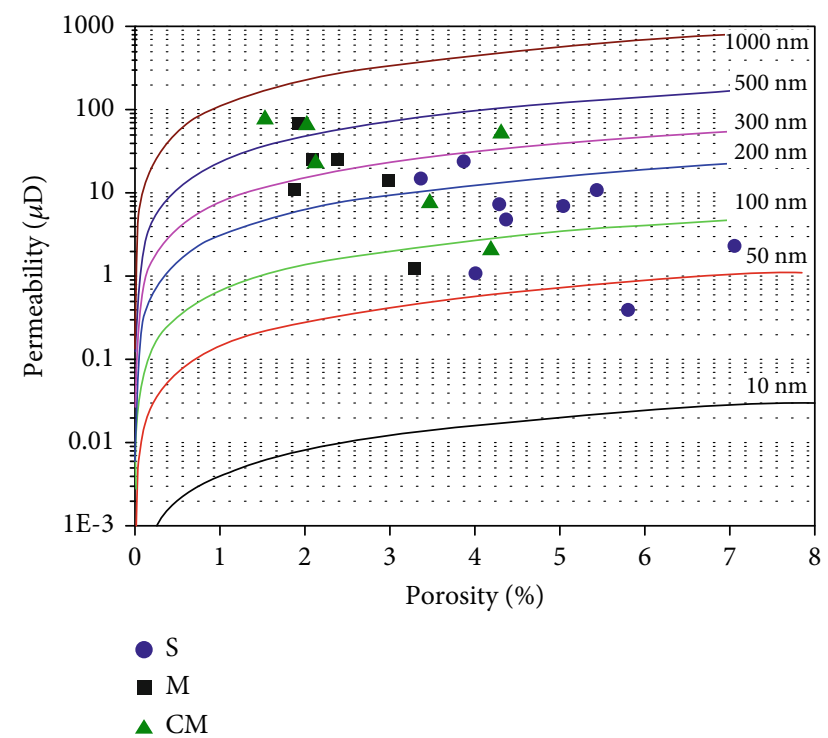

FIGURE 17: The crossplot of Klinkenberg-corrected permeability versus porosity along with the lines based on the Winland equation [59] for different values of $\boldsymbol{r}_{p 35}$.

(2) The intrinsic permeability of Longmaxi shales parallel to bedding $\left(K_{\mathrm{h}}\right)$ ranges between 0.4 and $76.6 \mu \mathrm{D}$. The average parallel to bedding permeability values decreases in a descending order: CM shales (averaging $37.6 \mu \mathrm{D}$ ) $>\mathrm{M}$ shales (averaging $24.4 \mu \mathrm{D}$ ) $>\mathrm{S}$ shales (averaging $8.2 \mu \mathrm{D}$ ). Permeability anisotropy of shales varies from 1.3 to 49.8

(3) Permeability of these shales mainly depends on the rock microfabric, other than TOC content and porosity. There is a negative correlation between permeability values and porosities of the samples studied. Samples with well-developed laminae and oriented clay flakes show higher permeability and permeability anisotropy
(4) The effective transport pore diameter was estimated using two different methods: gas slippage measurements and the Winland equation. The effective transport pore diameters of argillaceous shales (averaging $552 \mathrm{~nm}$ ) are commonly larger than those of siliceous shales (averaging 198 nm), which is related to the preferential transport pathways of laminated fabric and intraparticle pores of oriented clay minerals

\section{Data Availability}

Data will be made available upon request.

\section{Conflicts of Interest}

The authors declare that they have no conflicts of interest.

\section{Acknowledgments}

The authors would like to acknowledge the financial support of the National Natural Science Foundation of China (Grant Nos. 41690134, 41821002, 51604249, and 41702155), the Programme of Introducing Talents of Discipline to Universities (No. B14031), and the Open Research Fund of Teaching Laboratory, China University of Geosciences (Wuhan) (No. SKJ2018019).

\section{References}

[1] J. B. Curtis, "Fractured shale-gas systems," AAPG Bulletin, vol. 86, pp. 1921-1938, 2002.

[2] R. Rezaee, Fundamentals of Gas Shale Reservoirs, Published by John Wiley \& Sons, Hoboken, New Jersey, USA, 2015.

[3] D. A. V. Stow and D. J. W. Piper, "Deep-water fine-grained sediments: facies models," Geological Society, London, Special Publications, vol. 15, no. 1, pp. 611-646, 1984.

[4] C. R. Clarkson, N. Solano, R. M. Bustin et al., "Pore structure characterization of North American shale gas reservoirs using USANS/SANS, gas adsorption, and mercury intrusion," Fuel, vol. 103, pp. 606-616, 2013. 
[5] X. Dong, H. Liu, J. Hou, K. Wu, and Z. Chen, "Phase equilibria of confined fluids in nanopores of tight and shale rocks considering the effect of capillary pressure and adsorption film," Industrial and Engineering Chemistry Research, vol. 55, no. 3, pp. 798-811, 2016.

[6] R. G. Loucks, R. M. Reed, S. C. Ruppel, and D. M. Jarvie, "Morphology, genesis, and distribution of nanometer-scale pores in siliceous mudstones of the Mississippian Barnett Shale," Journal of Sedimentary Research, vol. 79, no. 12, pp. 848-861, 2009.

[7] R. G. Loucks, R. M. Reed, S. C. Ruppel, and U. Hammes, "Spectrum of pore types and networks in mudrocks and a descriptive classification for matrix-related mudrock pores," AAPG Bulletin, vol. 96, no. 6, pp. 1071-1098, 2012.

[8] C. Lyu, Z. Ning, Q. Wang, and M. Chen, "Application of NMRT2to pore size distribution and movable fluid distribution in tight sandstones," Energy \& Fuels, vol. 32, no. 2, pp. 1395-1405, 2018.

[9] R. Holmes, H. Aljamaan, V. Vishal, J. Wilcox, and A. R. Kovscek, "Idealized shale sorption isotherm measurements to determine pore capacity, pore size distribution, and surface area," Energy \& Fuels, vol. 33, no. 2, pp. 665-676, 2019.

[10] M. Mastalerz, A. Schimmelmann, A. Drobniak, and Y. Chen, "Porosity of Devonian and Mississippian New Albany shale across a maturation gradient: insights from organic petrology, gas adsorption, and mercury intrusion," AAPG Bulletin, vol. 97, no. 10, pp. 1621-1643, 2013.

[11] R. M. Slatt and N. R. O'Brien, "Pore types in the Barnett and Woodford gas shales: contribution to understanding gas storage and migration pathways in fine-grained rocks," AAPG Bulletin, vol. 95, no. 12, pp. 2017-2030, 2011.

[12] L. Chen, Z. Jiang, K. Liu, J. Tan, F. Gao, and P. Wang, "Pore structure characterization for organic-rich Lower Silurian shale in the Upper Yangtze Platform, South China: a possible mechanism for pore development," Journal of Natural Gas Science and Engineering, vol. 46, pp. 1-15, 2017.

[13] J. Li, K. Wu, Z. Chen et al., "Effects of energetic heterogeneity on gas adsorption and gas storage in geologic shale systems," Applied Energy, vol. 251, p. 113368, 2019.

[14] K. L. Milliken, M. Rudnicki, D. N. Awwiller, and T. Zhang, "Organic matter-hosted pore system, Marcellus formation (Devonian), Pennsylvania," AAPG Bulletin, vol. 97, no. 2, pp. 177-200, 2013.

[15] Q. R. Passey, K. Bohacs, W. L. Esch, R. Klimentidis, and S. Sinha, "From oil-prone source rock to gas-producing shale reservoir-geologic and petrophysical characterization of unconventional shale gas reservoirs," in International Oil and Gas Conference and Exhibition in China, Beijing, China, 2010.

[16] F. Yang, Z. Ning, Q. Wang, R. Zhang, and B. M. Krooss, "Pore structure characteristics of lower Silurian shales in the southern Sichuan Basin, China: Insights to pore development and gas storage mechanism," International Journal of Coal Geology, vol. 156, pp. 12-24, 2016.

[17] K. Wu, Z. Chen, X. Li, C. Guo, and M. Wei, “A model for multiple transport mechanisms through nanopores of shale gas reservoirs with real gas effect-adsorption-mechanic coupling," Heat and Mass Transfer, vol. 93, pp. 408-426, 2016.

[18] K. Wu, Z. Chen, X. Li et al., "Flow behavior of gas confined in nanoporous shale at high pressure: real gas effect," Fuel, vol. 205, pp. 173-183, 2017.

[19] R. Fink, B. M. Krooss, and A. Amann-Hildenbrand, "Stressdependence of porosity and permeability of the Upper Jurassic
Bossier shale: an experimental study," Geological Society London Special Publications, vol. 454, no. 1, pp. 107-130, 2017.

[20] G. R. L. Chalmers, D. J. K. Ross, and R. M. Bustin, “Geological controls on matrix permeability of Devonian gas shales in the Horn River and Liard basins, northeastern British Columbia, Canada," International Journal of Coal Geology, vol. 103, pp. 120-131, 2012.

[21] Y. Yang and A. C. Aplin, "Permeability and petrophysical properties of 30 natural mudstones," Journal of Geophysical Research, vol. 112, no. B3, 2007.

[22] M. Pommer and K. Milliken, "Pore types and pore-size distributions across thermal maturity, Eagle Ford Formation, southern Texas," AAPG Bulletin, vol. 99, no. 9, pp. 1713-1744, 2015.

[23] P. Psarras, R. Holmes, V. Vishal, and J. Wilcox, "Methane and $\mathrm{CO}_{2}$ adsorption capacities of kerogen in the eagle ford shale from molecular simulation," Accounts of Chemical Research, vol. 50, no. 8, pp. 1818-1828, 2017.

[24] X. Tang, Z. Jiang, H. Huang et al., "Lithofacies characteristics and its effect on gas storage of the Silurian Longmaxi marine shale in the southeast Sichuan Basin, China," Journal of Natural Gas Science and Engineering, vol. 28, pp. 338-346, 2016.

[25] F. Yang, Z. Ning, R. Zhang, H. Zhao, and B. M. Krooss, "Investigations on the methane sorption capacity of marine shales from Sichuan Basin, China," International Journal of Coal Geology, vol. 146, pp. 104-117, 2015.

[26] H. Qinhong, Y. Zhang, X. Meng, L. Zheng, Z. Xie, and L. Maowen, "Characterization of micro-nano pore networks in shale oil reservoirs of Paleogene Shahejie Formation in Dongying Sag of Bohai Bay Basin, East China," Petroleum Exploration and Development, vol. 44, no. 5, pp. 720-730, 2017.

[27] F. Rashid, P. W. J. Glover, P. Lorinczi, D. Hussein, R. Collier, and J. Lawrence, "Permeability prediction in tight carbonate rocks using capillary pressure measurements," Marine and Petroleum Geology, vol. 68, pp. 536-550, 2015.

[28] Z. Gao and Q. Hu, "Estimating permeability using median pore-throat radius obtained from mercury intrusion porosimetry," Journal of Geophysics and Engineering, vol. 10, no. 2, article 025014, 2013.

[29] L. J. Klinkenberg, The permeability of porous media to liquids and gases, American Petroleum Institute, New York, New York, 1941.

[30] D. M. Jarvie, R. J. Hill, T. E. Ruble, and R. M. Pollastro, "Unconventional shale-gas systems: the Mississippian Barnett shale of north-central Texas as one model for thermogenic shale-gas assessment," AAPG Bulletin, vol. 91, no. 4, pp. 475-499, 2007.

[31] J. Tan, B. Horsfield, R. Fink et al., "Shale gas potential of the major marine shale formations in the Upper Yangtze Platform, South China, part III: mineralogical, lithofacial, petrophysical, and rock mechanical properties," Energy \& Fuels, vol. 28, no. 4, pp. 2322-2342, 2014.

[32] B. Bruns, R. Littke, M. Gasparik, J.-D. van Wees, and S. Nelskamp, "Thermal evolution and shale gas potential estimation of the Wealden and Posidonia Shale in NW-Germany and the Netherlands: a 3D basin modelling study," Basin Research, vol. 28, no. 1, pp. 2-33, 2016.

[33] R. Littke, J. L. Urai, A. K. Uffmann, and F. Risvanis, "Reflectance of dispersed vitrinite in Palaeozoic rocks with and without cleavage: implications for burial and thermal history modeling in the Devonian of Rursee area, northern Rhenish 
Massif, Germany," International Journal of Coal Geology, vol. 89, pp. 41-50, 2012.

[34] A. T. Stock, R. Littke, J. Schwarzbauer, B. Horsfield, and C. Hartkopf-Fröder, "Organic geochemistry and petrology of Posidonia Shale (Lower Toarcian, Western Europe) - The evolution from immature oil-prone to overmature dry gas- producing kerogen," International Journal of Coal Geology, vol. 176-177, pp. 36-48, 2017.

[35] K. Wu, X. Li, C. Wang, W. Yu, and Z. Chen, "Model for surface diffusion of adsorbed gas in nanopores of shale gas reservoirs," Industrial and Engineering Chemistry Research, vol. 54, no. 12, pp. 3225-3236, 2015.

[36] H. Zhao, Z. Ning, T. Zhao, R. Zhang, and Q. Wang, "Effects of mineralogy on petrophysical properties and permeability estimation of the Upper Triassic Yanchang tight oil sandstones in Ordos Basin, Northern China," Fuel, vol. 186, pp. 328-338, 2016.

[37] A. Ghanizadeh, A. Amann-Hildenbrand, M. Gasparik, Y. Gensterblum, B. M. Krooss, and R. Littke, "Experimental study of fluid transport processes in the matrix system of the European organic-rich shales: II. Posidonia Shale (Lower Toarcian, northern Germany)," International Journal of Coal Geology, vol. 123, pp. 20-33, 2014.

[38] A. Ghanizadeh, C. R. Clarkson, S. Aquino, O. H. Ardakani, and H. Sanei, "Petrophysical and geomechanical characteristics of Canadian tight oil and liquid-rich gas reservoirs: I. pore network and permeability characterization," Fuel, vol. 153, pp. 664-681, 2015.

[39] Q. Hu, R. P. Ewing, and H. D. Rowe, "Low nanopore connectivity limits gas production in Barnett formation," Journal of Geophysical Research: Solid Earth, vol. 120, no. 12, pp. 80738087, 2015.

[40] J. J. Hickey and B. Henk, "Lithofacies summary of the Mississippian Barnett shale, mitchell 2 T.P. Sims well, Wise County, Texas," AAPG Bulletin, vol. 91, no. 4, pp. 437-443, 2007.

[41] R. G. Loucks and S. C. Ruppel, "Mississippian Barnett Shale: lithofacies and depositional setting of a deep-water shale-gas succession in the Fort Worth Basin, Texas," AAPG Bulletin, vol. 91, no. 4, pp. 579-601, 2007.

[42] J. Dai, C. Zou, S. Liao et al., "Geochemistry of the extremely high thermal maturity Longmaxi shale gas, southern Sichuan Basin," Organic Geochemistry, vol. 74, pp. 3-12, 2014.

[43] T. Guo, "Evaluation of highly thermally mature shale-gas reservoirs in complex structural parts of the Sichuan Basin," Journal of Earth Science, vol. 24, no. 6, pp. 863-873, 2013.

[44] F. Hao, T. Guo, Y. Zhu, X. Cai, H. Zou, and P. Li, "Evidence for multiple stages of oil cracking and thermochemical sulfate reduction in the Puguang gas field, Sichuan Basin, China," AAPG Bulletin, vol. 92, no. 5, pp. 611-637, 2008.

[45] F. Hao, H. Zou, and Y. Lu, "Mechanisms of shale gas storage: implications for shale gas exploration in China," AAPG Bulletin, vol. 97, no. 8, pp. 1325-1346, 2013.

[46] L. Chen, Z. Jiang, K. Liu et al., "Effect of lithofacies on gas storage capacity of marine and continental shales in the Sichuan Basin, China," Journal of Natural Gas Science and Engineering, vol. 36, pp. 773-785, 2016.

[47] T. Guo and H. Zhang, "Formation and enrichment mode of Jiaoshiba shale gas field, Sichuan Basin," Petroleum Exploration and Development, vol. 41, no. 1, pp. 31-40, 2014.

[48] X. Guo, D. Hu, Y. Li, Z. Wei, X. Wei, and Z. Liu, "Geological factors controlling shale gas enrichment and high production in Fuling shale gas field," Petroleum Exploration and Development, vol. 44, no. 4, pp. 513-523, 2017.

[49] Y. F. Li, D. Y. Shao, H. G. Lv, Y. Zhang, X. L. Zhang, and T. W. Zhang, "A relationship between elemental geochemical characteristics and organic matter enrichment in the marine shale of Wufeng Formation-Longmaxi Formation Sichuan Basin," Acta Petrolei Sinica, vol. 36, pp. 1470-1483, 2015.

[50] C. L. Mu, K. K. Zhou, W. Liang, and X. Y. Ge, "Early Paleozoic sedimentary environment of hydrocarbon source rocks in the Middle-Upper Yangtze Region and petroleum and gas exploration," Acta Geologica Sinica, vol. 85, no. 4, pp. 526-532, 2011.

[51] L. Zhang, B. Li, S. Jiang et al., "Heterogeneity characterization of the lower Silurian Longmaxi marine shale in the Pengshui area, South China," International Journal of Coal Geology, vol. 195, pp. 250-266, 2018.

[52] Z. F. Wang, Y. F. Zhang, X. L. Liang et al., "Characteristics of shale lithofacies formed under different hydrodynamic conditions in the Wufeng-Longmaxi Formation, Sichuan Basin," Acta Petrolei Sinica, vol. 35, no. 4, pp. 623-632, 2014.

[53] S. J. Gregg and K. S. W. Sing, Adsorption, surface area and porosity, Academic Press, New York, 2nd edition, 1982.

[54] W. C. Krumbein, "Lithofacies maps and regional sedimentarystratigraphic analysis," AAPG Bulletin, vol. 32, no. 10, pp. 1909-1923, 1948.

[55] U. Kuila, D. K. McCarty, A. Derkowski, T. B. Fischer, T. Topór, and M. Prasad, "Nanoscale texture and porosity of organic matter and clay minerals in organic-rich mudrocks," Fuel, vol. 135, pp. 359-373, 2014.

[56] A. R. Bhandari, P. B. Flemings, P. J. Polito, M. B. Cronin, and S. L. Bryant, "Anisotropy and stress dependence of permeability in the Barnett shale," Transport in Porous Media, vol. 108, no. 2, pp. 393-411, 2015.

[57] G. Gaus, A. Amann-Hildenbrand, B. M. Krooss, and R. Fink, "Gas permeability tests on core plugs from unconventional reservoir rocks under controlled stress: a comparison of different transient methods," Journal of Natural Gas Science and Engineering, vol. 65, pp. 224-236, 2019.

[58] C. R. Clarkson, J. L. Jensen, P. K. Pedersen, and M. Freeman, "Innovative methods for flow-unit and pore-structure analyses in a tight siltstone and shale gas reservoir," AAPG Bulletin, vol. 96, no. 2, pp. 355-374, 2012.

[59] R. Aguilera, "Incorporating capillary pressure, pore aperture radii, height above free water table, and Winland $r_{35}$ values on Picket plots," AAPG Bulletin, vol. 86, pp. 605-624, 2002. 